\title{
Second-generation antipsychotic drugs and short-term somatic serious adverse events: a systematic review and meta-analysis of placebo-controlled randomised controlled trials
}

Word count: abstract 341, main text 4190; figures 1; tables 5

Authors: Johannes Schneider-Thoma, Orestis Efthimiou, Irene Bighelli, Carola Dörries, Maximilian Huhn, Marc Krause, Leonie Reichelt, Hannah Röder, Toshi A Furukawa, John M Davis, Stefan Leucht*

*Corresponding author: Stefan Leucht, MD, Department of Psychiatry and Psychotherapy, Klinikum rechts der Isar, Technical University of Munich, Ismaninger Straße 22, 81675 München, Germany, Email: Stefan.leucht@tum.de

Affiliations: Department of Psychiatry and Psychotherapy, School of Medicine, Technical University of Munich, , Munich, Germany (J Schneider-Thoma MD, I Bighelli PhD, C Dörries, M Huhn MD, M Krause MA, L Reichelt, H Röder, S Leucht MD); Institute for Evidence in Medicine (for Cochrane Germany Foundation), Medical Center - University of Freiburg, Faculty of Medicine, University of Freiburg, Germany (M Krause MA); Institute of Social and Preventive Medicine, University of Bern, Bern, Switzerland (O Efthimiou PhD); Department of Health Promotion and Human Behavior, Kyoto University Graduate School of Medicine/School of Public Health, Kyoto, Japan (Prof T A Furukawa); Psychiatric Institute, University of Illinois at Chicago, Chicago, IL, USA (Prof J M Davis MD); and Maryland Psychiatric Research Center, Baltimore, MD, USA (J M Davis MD) 


\section{SUMMARY}

\section{Background}

Antipsychotic drugs might cause acutely-occurring serious side effects and thus contribute to the increased physical morbidity and mortality observed in patients with severe mental disorders. We examined this hypothesis by conducting a meta-analysis of ICH-GCP-defined serious adverse events (SAEs) occurring in placebo-controlled trials of antipsychotics.

\section{Methods}

For this systematic review and meta-analysis (PROSPERO \#CRD42016033930), we included randomised controlled trials (RCTs) comparing second-generation antipsychotics with placebo across diagnostic categories. We searched MEDLINE, EMBASE, Cochrane CENTRAL, BIOSIS, PsycINFO, Pubmed, Clinicaltrials.gov and WHO ICTRP (last search 01/27/2017) for eligible trials. We contacted pharmaceutical companies, drug regulatory authorities and study investigators for additional data. The primary outcome was the number of patients with at least one somatic SAE. We estimated minimum and maximum numbers of patients with the outcome in each study arm and synthesized the results with Odds Ratios in a common-effects metaanalysis.

\section{Findings}

We identified 597 RCTs comprising 108664 participants. 314 trials (67642 participants) with details on individual SAEs available constituted the main dataset for meta-analysis. 88\% of these were 13 weeks (3 month) or shorter in duration (median 6, IQR 4-9 weeks). At least one somatic SAE occurred in minimally 698 to maximally 862 of 42600 patients (1.63-2.02\%) on antipsychotics and in minimally 343 to maximally 419 of 25042 (1.37\%-1.67\%) patients on placebo. The odds ratios were 1.24 (95\%CI 1.08, 1.42) and 1.24 (95\%CI 1.10, 1.41) based on the minimum and maximum estimate respectively. In predefined subgroup-analyses we found evidence suggesting a larger effect in elderly patients (OR 1.56; 95\%CI 1.22, 1.98)/OR 1.58; 95\%CI 1.25, 1.99) as compared to adults (OR 1.09; 95\%CI 0.91, 1.29)/OR 1.10; 95\%CI 0.95, 1.28); likewise in children/adolescents although the evidence was weaker (OR 1.49; 95\%CI 0.81, 2.75/OR 1.54; 95\%CI 0.85, 2.77).

\section{Interpretation}

We found evidence that antipsychotics cause short-term somatic SAEs on top of somatic SAEs occurring independent of treatment. This effect appears to be mainly driven by results in elderly patients. Hence, clinicians should be aware that antipsychotics are potentially toxic, particularly when treating patients sharing risk factors with the elderly population.

\section{Funding}

German Ministry of Education and Research (FKZ01KG1505) 


\section{INTRODUCTION}

Patients with schizophrenia and other severe mental disorders have higher rates of physical disorders ${ }^{1,2}$ and live on average 14.5 years less compared to the general population. ${ }^{3}$ Treatment with antipsychotic drugs is suspected to contribute to the increased morbidity and mortality by causing acutely-occurring serious side effects and through the consequences of chronicallypersisting side effects such as weight gain. Indeed, in observational data use of antipsychotics has been associated with higher incidences of several serious physical disorders that may arise from acutely-occurring side effects, such as thromboembolisms, diabetic ketoacidosis, cardiac arrhythmias, pneumonia, hepatic injuries, seizures, malignant neuroleptic syndrome, or leukocytopenia and agranulocytosis. ${ }^{4}$ However, association is not always due to causality. Associations found in observational data may be confounded by factors such as differences in severity of illness, comorbidities, health-relevant life style, or utilization and access to health care between treated patients and controls. ${ }^{4}$

Randomised controlled trials (RCTs) are considered the best study design to examine causality and in modern RCTs it is mandatory to record serious adverse events (SAE) $)^{5,6}$ as part of International-Council-for-Harmonization-Good-Clinical-Practice (ICH-GCP) guidelines. ${ }^{7}$ A SAE is defined as any untoward medical occurrence at any dose that results in death, is lifethreatening, requires inpatient hospitalization or prolongation of existing hospitalization, results in persistent or significant disability or is a congenital anomaly or birth defect. By metaanalyzing SAEs that occurred in RCTs comparing antipsychotic drugs to placebo, we aimed to examine whether antipsychotics cause (directly or indirectly) acutely-occurring serious side effects (of any kind) and thus contribute to the observed increased morbidity and mortality in patients with severe mental disorders. Hereby, we complement our previously published metaanalysis on short-term mortality in placebo-controlled RCTs of antipsychotics. ${ }^{8}$ To our knowledge, this is the first analysis of this kind (see research in context). 


\section{METHODS}

This systematic review and meta-analysis was conducted in the context of a broader project sponsored by the German Ministry of Education and Research which also comprises an

assessment of mortality reported previously. ${ }^{8}$ The analysis of mortality used the same literature search and methods (inclusion criteria, statistical methods, sensitivity and subgroup/metaregression analyses), but analyzed as outcome mortality (irrespective whether fatal events were reported as SAE or not). The protocol for both analyses (mortality, SAEs) was published in PROSPERO (\#CRD42016033930, appendix). In reporting the meta-analysis, we followed the PRISMA statement ${ }^{9}$ (checklist in appendix).

\section{Search strategy and selection criteria}

We included randomised controlled trials (RCTs) comparing second-generation antipsychotic drugs (SGAs) to placebo across any indications. Thus patients in a wide range of diagnostic categories (e.g., schizophrenia, bipolar disorder, major depression, dementia, autism) were eligible, because we assumed that side effects occur largely independent of the treated mental disease. There were no limitations in age, sex or ethnicity of the study populations.

We included studies that compared placebo to any SGA currently available in the US or Europe, i.e., amisulpride, aripiprazole, asenapine, brexpiprazole, cariprazine, clozapine, iloperidone, lurasidone, olanzapine, paliperidone, quetiapine, risperidone, sertindole, ziprasidone and zotepine. We also included first-generation antipsychotics (FGAs) that were used as additional active comparators in placebo-controlled trials of SGAs. There were no restrictions in mode of application (oral, intravenous, inhalers, short- and long-acting (depot) intramuscular applications), doses (any dose, in flexible and fixed dosing regimens), or additional treatments (monotherapy or add-on treatment). 
We included double-blind, single-blind, and open-label RCTs. However, we excluded a priori studies with a high risk of bias in sequence generation for randomisation or allocation concealment. ${ }^{10}$ There was no restriction in terms of study duration. Only very short studies $(\leq 24$ hours) measuring psychological reactions to drugs (e.g. fMRI studies) were excluded. In general, we included studies irrespective of publication year and language. However, we excluded studies conducted in mainland China because of major concerns about study quality. $^{11-14}$

To identify eligible studies, we searched the electronic databases MEDLINE, EMBASE, Cochrane CENTRAL, BIOSIS, PsycINFO, Pubmed, Clinicaltrials.gov and WHO ICTRP (all from inception, last search 01/27/2017). The search strategy used terms for randomisation, the generic names of the included second-generation antipsychotics and terms for placebo (see appendix for details). Additionally, we manually searched the European Union Clinical Trials Register (EUCTR). We also contacted the manufacturers of the antipsychotics, the Food and Drug Administration (FDA), the European Medicines Agency (EMA), and the German “Bundesinstitut für Arzneimittel und Medizinprodukte” (BfArM), and searched their clinical trial websites. Moreover, we contacted all corresponding authors of the included trials for missing information.

JS-T, HR and LR, in duplicate, screened the identified references and selected the finally included studies. Also in duplicate, JS-T, CD, IB, HR, LR, MH and MK extracted data using an electronic database (this system checked automatically whether independent extractions agreed) and assessed the risk of bias of the included studies using the Cochrane-risk-of-biastool- ${ }^{10}$ (overall risk of bias evaluation performed according to Cipriani et al. $2018^{15}$ ). Disagreement was resolved by discussion among reviewers or with a third reviewer (JS-T or SL). JS-T and SL contacted drug regulatory authorities and pharmaceutical companies and sent 
personalized emails to all corresponding authors (including authors of protocols without usable data, see figure 1) with requests for missing data.

\section{Data analysis}

The primary outcome was the number of patients with at least one somatic serious adverse event (SAE) per study arm. As secondary outcomes we examined the number of patients with at least one psychiatric SAE and the number of patients with at least one SAE (any SAE, somatic or psychiatric). We separated somatic from psychiatric SAEs because according to the broad definition of SAEs (see introduction) exacerbations of the treated psychiatric disorders (typically leading to hospitalization) are also reported as SAEs. However, such psychiatric SAEs rather reflect treatment-inefficacy, and not serious side effects which are the focus of our analysis. We used all reported SAEs and not only SAEs that were attributed to the drug by the original study investigators (ICH-GCP-defined serious adverse reactions (SAR) ${ }^{16}$ ). The reasons were that information on SARs was only rarely reported and that we did not want to base our analysis on subjective judgement of original trial investigators (SARs were analyzed in a sensitivity analysis).

As the number of patients with at least one somatic or psychiatric SAE was typically not provided in reports of clinical trials, we estimated it from listings of individual SAEs. Therefore, we classified individual SAEs according to the Medical-Dictionary-for-Regulatory-Activities (MedDRA) $)^{17}$ and considered events categorized in the system-organ-class (SOC) "Psychiatric disorder” as psychiatric SAEs. All others we considered somatic SAEs. Because individual patients could have had more than one SAE, we estimated the minimum and maximum number of patients with at least one somatic (psychiatric) SAE. See appendix for a detailed explanation of how the estimates were calculated. 
We analyzed the data using the common-effect (“fixed-effect”) Mantel-Haenszel meta-analysis model with odds ratios (OR) because estimation of heterogeneity is difficult for rare events. With this decision we followed the Cochrane Handbook which suggests "incorporation of heterogeneity into an estimate of a treatment effect should be a secondary consideration when attempting to produce estimates of effects from sparse data - the primary concern is to discern whether there is any signal of an effect in the data”. ${ }^{10,18}$ We synthesized OR and not hazard ratios because time-to-event data were usually not reported. The Mantel-Haenszel-method uses only studies with at least one event (number of used studies and included patients provided in tables of results). In sensitivity analyses we examined models including studies with zero events $^{18,19}$ or models assuming random effects. We included SAEs that occurred in the randomised phase or within the studies' predefined safety follow-up phases after study discontinuation or completion (usually lasting 30 days). From cross-over studies we used only the first phases to avoid carry-over effects. ${ }^{20}$ We assessed heterogeneity statistically by estimating $\tau^{2}, \mathrm{I}^{2}$ and by performing a Q-test. ${ }^{10}$ We examined the presence of small study effects (linked with the possibility of publication bias) by visually inspecting funnel plots and performing Harbord-tests. ${ }^{21}$

We performed several pre-planned sensitivity analyses to examine the robustness of our results for the primary outcome:

1) We only included SAEs that occurred during the randomised phase or within 24 hours after the last drug administration, i.e., we excluded SAEs that occurred in the safetyfollow up. The reason was that effects of the randomised drug may be diluted in the safety follow-up because patients do not follow strict study conditions anymore, e.g., they may not take the study drug but may take others, or no drugs. 
2) We analyzed incidence rates, i.e., we used the number of patients with at least one somatic SAE and the total patient-years per study arm. The reason was that there may be differences in premature study discontinuation between drug- and placebo-arms that could affect the primary effect size measure (odds ratio). If information about the total patient-years spent in the study was not available, it was estimated from study duration and number of dropouts, after assuming a linear rate of discontinuation over time.

3) We analyzed the data using different models for meta-analysis, i.e. Peto’s odds ratios, a correlated beta-binomial (Sarmanov) model, Bayesian common-effects and randomeffects models. For the latter we used an informative prior distribution for heterogeneity. ${ }^{22}$ Of note, the beta-binomial model and the Bayesian models use information from studies without SAE.

4) We analyzed SAEs judged as at least possibly treatment-related by original study investigators separately (SARs, including suspected unexpected SARs (SUSARs)).

5) We only included double-blind studies.

We performed several pre-planned subgroup and meta-regression analyses of the primary outcome to examine potential treatment effect modifiers.

Separate (univariate) subgroup analyses addressed:

1) Study duration (<6 days; 6 days to 13 weeks; $>13$ weeks).

2) Age groups (children and adolescents; adults; elderly).

3) Diagnostic category.

4) Specific antipsychotic used.

5) Monotherapy versus combinations of antipsychotics (any systematic combination; addon to antidepressants, mood stabilizers or antipsychotics).

6) First-generation versus second-generation antipsychotics. 
7) Sponsorship by pharmaceutical companies.

Separate (univariate) meta-regression analyses addressed:

1) The proportion of women enrolled.

2) Antipsychotic dose in olanzapine equivalents, calculated based on the International Consensus Study of Antipsychotic Dosing. ${ }^{23}$ Here, only studies of oral drugs in adult patients were included because dose equivalencies are not well specified for other age groups and applications.

For our main findings, we additionally estimated risk differences (RDs) based on summary ORs and incidences on placebo as baseline risk. Risk differences are often preferred for reasons of interpretability.${ }^{10}$ However, readers must be aware that RDs are conditional on baseline risk, which may be different in other settings.

Post-hoc, we analyzed somatic SAEs grouped by individual MedDRA-SOCs ${ }^{17}$ (overall, by age group and for the diagnostic categories schizophrenia and dementia).

We performed meta-analysis using the Mantel-Haenszel and Peto methods in $\mathrm{R}^{24}$ using the package meta. ${ }^{25}$ We fitted the correlated beta-binomial model in R using the code provided by Chen et al. ${ }^{26}$ We synthesized incidence rates in $\mathrm{R}$ using the metafor package, ${ }^{27}$ fitting a random-effects generalized linear model with a Poisson likelihood. We performed all Bayesian analysis in OpenBUGS. ${ }^{28,29}$ See appendix for details of the statistical models.

The strength of the evidence was assessed with the GRADE framework ${ }^{30}$ using the online tool GRADE PRO (https://gradepro.org/).

\section{Role of the funding source}


The funder of the study had no role in study design, data collection, data analysis, data interpretation or writing of the report. The corresponding author had full access to all the data in the study and had final responsibility for the decision to submit for publication. 


\section{RESULTS}

We present the PRISMA ${ }^{9}$ flow diagram in figure 1 and the characteristics of included studies in the appendix. We identified 597 RCTs (dating from 1978 to 2017) with a total of 108664 participants.

368 trials (89731 patients) reported whether any SAE occurred in the included patients. Out of these, 314 trials (67642 patients) reported details about individual SAEs, which allowed us to estimate the minimum and maximum number of patients with at least one somatic SAE. These 314 studies constitute our main dataset. In the main dataset, most patients' illnesses were in the diagnostic categories of schizophrenia (42\% of all patients), bipolar disorder (30\%), major depressive disorder (11\%) and dementia (6\%). The remaining patients (11\%) were in an additional 17 officially-approved or off-label indications for antipsychotics. Most patients (83\%) were adults (in trials typically defined as 18-65 years), 8\% elderly (typically >65 years) and $9 \%$ children and adolescents (typically $<18 y$ ). $46 \%$ of patients were women. The most frequently used drugs were olanzapine (17\% of 42600 patients treated with active drug), aripiprazole (16\%), quetiapine (11\%), paliperidone (11\%), risperidone (11\%), asenapine (7\%), lurasidone (7\%) and brexpiprazole (6\%); the remaining 14\% of patients were treated with 7 additional antipsychotics (including the first-generation antipsychotics (FGAs) haloperidol (5\%) and chlorpromazine (0.2\%) used as active comparators in placebo-controlled studies of SGAs). 306 (97\%) trials were double blind. 263 (84\%) were sponsored by pharmaceutical companies. The median duration of trials was 6 weeks (IQR 4-9 weeks). 276 (87.9\%) trials were 13 weeks (3 months) or less in duration. None of the included studies was set out to specifically examine serious adverse events as the main outcome.

We present the risk of bias assessment in the appendix. We conservatively judged all studies for which we could not acquire information about individual SAEs at risk of selective reporting. Therefore, 254 of 597 trials (43\%) were rated at high risk of bias in this category. Ratings of 
high risk of bias were rare in other categories: none of 597 for randomisation, none for allocation concealment, 19 (3\%) for blinding of participants and personal, 14 (2\%) for blinding of outcome assessment, 11 (2\%) for incomplete outcome data, and 15 (3\%) for other sources bias. In the overall risk of bias evaluation 30 trials (5\%) were rated at high, $358(60 \%)$ at moderate and 209 (35\%) at low risk of bias.

In all the following results, an odds ratio $>1$ corresponds to higher odds of SAEs with antipsychotics (favors placebo). Note that for rare events, odds and risks become very similar; hence, we also use the word "risk" instead of “odds” for reasons of readability.

Somatic SAEs (the primary outcome) were reported for minimally 698 to maximally 862 of 42600 patients (1.63-2.02\%) randomised to antipsychotics and for 343 to 419 of 25042 (1.37\%1.67\%) patients randomised to placebo (table 1). The summary OR was 1.24 for both analyses, i.e., using either the minimum or the maximum number of patients with at least one event. The 95\% CIs ranged from 1.10 to 1.41 and from 1.08 to 1.42 , respectively ( $k=196$ studies, $n=57850$ patients). These results indicate an increased risk of somatic SAEs for patients exposed to antipsychotic drugs.

Psychiatric SAEs (secondary outcome) were reported for 1038 to 1161 of 67598 patients randomised to antipsychotics (2.4\%-2.7\%) and 846 to 921 of 24992 patients randomised to placebo (3.4\%-3.7\%). The summary OR were 0.64 (95\%CI 0.58, 0.71) and 0.67 (95\%CI 0.61, 0.73) based on the minimum and maximum number of patients respectively ( $k=186, n=56381)$. These results indicate an increased risk of psychiatric SAEs for patients exposed to placebo. Any SAEs (secondary outcome), without distinguishing between somatic and psychiatric SAEs, were reported for 2445 of 56870 patients randomised to antipsychotics (4.3\%) and 1639 of 32861 patients randomised to placebo (5\%). The summary OR was 0.83 (95\% CI 0.77, 0.89, $\mathrm{k}=276, \mathrm{n}=84999$ ) indicating an increased risk of any SAE for patients exposed to placebo. 
Sensitivity analyses yielded results similar to the primary analysis (somatic SAEs) (table 2).

In subgroup analyses (table 3) we only found some evidence of effect modification according to age. More specifically, studies in elderly patients (OR 1.56; 95\%CI 1.22, 1.98)/OR 1.58; 95\%CI 1.25, 1.99) as well as in children/adolescent patients (OR 1.49; 95\%CI 0.81, 2.75/OR 1.54; 95\%CI 0.85, 2.77) showed a higher risk of somatic SAEs as compared to studies in adults (OR 1.09; 95\%CI 0.91, 1.29/OR 1.10; 95\%CI 0.95, 1.28).

The meta-regression analysis on proportion of women did not show evidence of a differential effect. The meta-regression on dosage provided some evidence that the risk for somatic SAEs increases with the mean dose applied in studies (regression coefficient based on minimum estimate 0.017 (95\%CI -0.003, 0.037); based on maximum estimate 0.023 (95\%CI 0.004 , 0.043)), corresponding to ORs rising gradually from $0.96 / 0.90$ for studies with a mean dose of $5 \mathrm{mg}$ to $1.25 / 1.27$ for studies with a mean dose of $20 \mathrm{mg}$ olanzapine equivalents.

There was no indication of small study effects (Harbord test $\mathrm{p}=0.12$ for minimum, $\mathrm{p}=0.26$ for maximum estimate; funnel-plots in appendix).

Overall there was little evidence for heterogeneity in both analyses of the primary outcome (minimum and maximum estimate). A visual inspection of the forest-plots (appendix) indicated some discrepancy between the studies estimates. The Q test for heterogeneity did not reject the null hypothesis of homogeneity, p-value 1.00 (minimum) and 0.97 (maximum estimate). The DerSimonian-and-Laird estimator for $\tau^{2}$ was zero in both analyses.

However, estimation of heterogeneity in an analysis of rare events, such as SAEs, can be difficult. Therefore, in order to assess the robustness of our results, we also performed a 
Bayesian sensitivity analysis including external information in the form of informative prior distributions $^{22}$ for heterogeneity. This analysis did not give markedly different results from the primary analysis (table 2).

The strength of the evidence was rated to be moderate for the primary outcome according to GRADE (evidence profile in appendix). ${ }^{30}$

Overall, our results correspond to RDs of 4/4 (minimally/maximally) more patients with somatic SAEs among 1000 treated (95\%CI ranging from 2/2 more to 6/7 more); in adults 1/2 more (95\%CI 1/1 less, 5/4 more); in children/adolescents 4/5 more (95\%CI 2/2 less, 17/19 more); in elderly 29/32 more (95\%CI 12/15 more, 49/54 more).

Post-hoc, to explore which kind of SAEs contributed to the observed increased risk, we analyzed somatic SAEs grouped by MedDRA-System-Organ-Classes (SOCs) (table 5). In the total sample, we found indications of differences between drug and placebo for A) "Infections and infestations”, B) “Musculoskeletal and connective tissue disorders”, C) "Nervous system disorders”, D) “Respiratory, thoracic and mediastinal disorders" and E) "Surgical and medical procedures”. In the elderly subgroup (appendix) we additionally found indications for F) “Cardiac disorders”, G) “Injury, poisoning and procedural complications” and H) "Vascular disorders”.

Within these SOCs the following MedDRA-subcategories - selected for specificity of the term - showed the highest absolute differences between drug and placebo (appendix: SAEs classified by MedDRA-hierarchy): "Lower respiratory tract and lung infections" (within A), "Rhabdomyolysis” (B), "Movement disorders” (C), “Central nervous system vascular disorders” (C), “Disturbances in consciousness NEC” (C; mainly syncope, somnolence and stupor), "Bronchospasm and obstruction" (D), and "Psychosocial support" (E). Except for 
“Rhabdomyolysis” “and "Movement disorders”, differences between drug and placebo were most prominent in elderly patients. In addition to the MedDRA-subcategories just mentioned in elderly also "Pneumonia aspiration” (D), "Surgery” (E), “Cardiac arrhythmias” (F), “Heart failures” (F), “Injury NEC” (G), “Hypotension” (H) and “Embolism and thrombosis” (H) were numerically increased with antipsychotics. There was no specific type of SAEs that explains the trend for an increased risk in children/adolescents.

Of note, statistical power was low, SOCs are broad categories and there may be chance findings due to multiple-testing; moreover, the selected MedDRA-subcategories are descriptive only. Consequently, there is limited evidence that the observed overall effect is due to differences in the mentioned categories and also other disorders may contribute. We emphasize that our results regarding specific disorders should thus be considered exploratory and hypothesis generating rather than confirmatory. 


\section{DISCUSSION}

In this systematic review and meta-analysis of 597 randomised controlled trials (comprising 108664 participants) we found evidence of an increased risk of somatic serious adverse events in patients treated with antipsychotic drugs as compared to patients treated with placebo. This result was consistent in several sensitivity analyses. Subgroup analyses suggested age as a potential treatment effect modifier with the highest risk found in studies in elderly patients, but also in studies with children/adolescents, although the evidence was weaker for the latter category.

A conceptual strength of the analysis is that it was based on randomised trials with a large total sample size (67642 patients from 314 trials in the meta-analysis of somatic SAEs). Thus it can be expected that all potential confounders were equally distributed across drug and placebo groups.

Specific strengths are the extensive search and the use of ICH-GCP-defined ${ }^{7}$ SAEs as an outcome, which are by definition selected for seriousness. We faced the issue that often SAEs were not reported or only the total number of patients with any SAE was provided. "Any SAE" is however a problematic outcome because it includes inefficacy-related psychiatric SAEs which are not relevant for assessing tolerability (and which are more frequent with placebo, see table 1). To overcome this problem, we extensively requested additional data (obtained for 244 trials) and, thus, could specifically estimate the risk of somatic SAEs - an outcome focusing on side effects. For future trials, we urge that somatic and psychiatric SAEs should be always reported separately.

Our analysis has limitations. First, we could not obtain details about specific SAEs for 54 studies which reported that at least one SAE occurred; for 229 studies we could not obtain information on SAEs at all; and for 72 studies we only found protocols. We deem it unlikely 
for most studies (see appendix: GRADE), but it cannot be excluded that in some studies information on somatic SAEs was suppressed intentionally (selective reporting), or that some planned studies were not published because of unfavorable safety data (publication bias). Second, although required by regulatory authorities, some SAEs may not have been assessed and reported ${ }^{31}$ (underreporting of adverse events is a general weakness of safety data from clinical trials). Third, sponsorship by pharmaceutical companies, as in most included trials, needs to be considered. Fourth, non-adherence to study medication may have diluted some of the differential effect. And fifth, particularly vulnerable patients with severe somatic comorbidities were often excluded from RCTs. These first five limitations potentially led to an underestimation of the incidences of somatic SAEs and/or the risk associated with antipsychotics relative to placebo. Mainly due to the probable underestimation of the effects as compared to routine care resulting from these limitations, we downgraded the strength of the evidence to moderate (appendix: GRADE).

Sixth, the available RCTs were mainly short-term in duration (88\% $\leq 3$ month). Consequently, we could not examine the risk of somatic SAEs related to chronically-persisting side effects of antipsychotics (e.g. weight gain). Seventh, event histories and information whether original investigators judged individual SAEs treatment-related (SAR) were often not reported. Thus, important indications which specific disorders might be increased by antipsychotics were missing (nevertheless 110 SARs could be tabulated (appendix)). Eighth, the subgroup analysis on specific drugs is limited in statistical power and by potential confounding (e.g. some antipsychotics were tested for dementia, others not). Further analyses including head-to-headstudies are needed to examine differences between antipsychotics. Ninth, we did not examine whether the method of dose increase of antipsychotics (rapid or slow) had an effect on occurrence of somatic SAEs. Finally, we acknowledge that the last search for eligible studies was conducted over 2 years ago (01/27/2017). Thus, some recently-published placebo- 
controlled studies were not included. However, we deem it unlikely that data of these trials would change the overall results (based on 597 studies published in 39 years).

Despite these limitations, our analysis provides randomised evidence that antipsychotic exposure can induce or aggravate serious somatic disorders - as suggested by associations found in observational studies. ${ }^{4}$ In line with observational studies, ${ }^{4,32,33}$ elderly patients and children/adolescents appeared particularly vulnerable also in our dataset. Concerning specific disorders possibly increased by antipsychotics, our exploratory and descriptive post-hocanalyses suggested several MedDRA-subcategories. For all of them associations with antipsychotics have been observed in real-world-populations. ${ }^{4,34-42}$ Yet, as we note in the results section, our approach for specific disorders is descriptive and other disorders may also be relevant - see appendix: tables of 3942 observed SAEs (and 110 SARs) classified by MedDRA-hierarchy (overall, by age group, and for the diagnostic categories schizophrenia and dementia). Of note, some SAEs may be indirect effects of treatment, e.g. drug-induced sedation and subsequent fall may result in the SAEs "fracture” and "pneumonia” (developed during hospitalization). More targeted approaches, such as Standardized-MedDRA-Queries (SMQs), applied in analyses focusing on specific disorders are required. For this reason and to avoid multiple post-hoc-analyses, we refrained from further analyzing specific disorders.

To put the results in relationship to our previous analysis on mortality, ${ }^{8}$ approximately $20 \%$ of patients with a somatic SAE died (30\% of elderly, $8 \%$ of adults, $0 \%$ of children). Subgroup analyses suggested increased mortality in elderly (mainly demented) patients and possibly increased somatic SAEs and reasons of deaths (appendix) overlap. In the total sample, pneumonia, overdose, injury, cerebrovascular disorder, and pneumonia aspiration were the reasons of deaths with the highest absolute difference between drug and placebo; except 
overdose they occurred mainly in elderly patients; in elderly also deaths due to cardiac failure were numerically increased. But these results are purely descriptive.

For clinical practice, we note that most occurring somatic SAEs were not related to the drug (incidence on placebo ca. $80 \%$ of incidence on drug). But on top of independently occurring events, antipsychotics led to 4 more patients with somatic SAEs per 1000 treated overall (adults 1-2; children/adolescents 4-5; elderly 29-32). We deem that this risk is not negligible, but that it may be acceptable in physically fit adults, despite possible underestimations, because substantial benefit can be expected. Individual patients sharing risk factors with the elderly population (e.g. somatic comorbidities, polypharmacy, higher age), and possibly children/adolescents, can be more vulnerable. 


\section{Contributors}

SL was the principal investigator of the review who supervised the study and obtained the funding. JS-T, OE, JMD, TAF, and SL designed the meta-analysis. JS-T, MH and SL set up the database. JS-T, HR, MH, LR and SL screened the literature search, acquired reports of relevant trials, identified multiple publications of individual studies and selected included studies. JS-T, CD, HR, IB, MH, MK, and LR extracted data. JS-T and SL contacted pharmaceutical companies, drug regulatory authorities and trial investigators for additional information. OE performed all statistical analyses. JS-T, OE, JD, TAF and SL analyzed and interpreted the data. JS-T, OE, TAF, JMD and SL wrote the draft and the final version of the report. All authors critically reviewed the report for important intellectual content and approved the final submitted version.

\section{Declaration of interests}

In the last 3 years, SL has received honoraria for consulting or lectures from LB Pharma, Lundbeck, Otsuka, TEVA, LTS Lohmann, Geodon Richter, Recordati, Boehringer Ingelheim, Sandoz, Janssen, Lilly, SanofiAventis, Servier and Sunovion. MH received lecture honoraria from Janssen and Lundbeck. TAF reports personal fees from Meiji, Mitsubishi-Tanabe, MSD and Pfizer and a grant from Mitsubishi-Tanabe, outside the submitted work; TAF has a patent 2018-177688 pending. All other authors declare that they have no conflicts of interest.

\section{Acknowledgements}

This work was supported by a grant from the German Ministry of Education and Research (Bundesministerium für Bildung und Forschung, BMBF, grant number: 01KG1505). OE was supported by the Swiss National Science Foundation (grant title: "Enhancing methods for evaluating the comparative safety of medical interventions”). 
We thank Samantha Roberts for conducting the electronic literature search and Thomas Arndt, Lio Bäckers, Natalie Peter and Philip Rothe for their help in the literature search, full text acquisition, cross-referencing, and data extraction. They had all been trained specifically for this purpose. We thank Georgia Salanti for her help in the conception of the statistical analysis. For sharing additional data about clinical trials we thank the European Medicines Agency (EMA) (for 31 trials of aripiprazole and 3 of lurasidone) and the pharmaceutical companies Eli Lilly (25 trials of olanzapine), Janssen (50 trials of risperidone, via the YODA project, \# 20160880, http://yoda.yale.edu/), Merck Sharp \& Dohme (15 trials of asenapine), Otsuka (10 trials of aripiprazole) and Vandapharma (4 trials of iloperidone). Furthermore, we thank all authors of the included studies, particularly those 112 authors, who answered our request and sent additional data for 86 trials. We state that the analysis, interpretation and reporting of research using provided data are solely the responsibility of the authors and do not necessarily represent the official views of the data-sharing institutions. We thank MedDRA for providing a free academic license of the Medical Dictionary for Regulatory Activities terminology (MedDRA ${ }^{\circledR}$, owned by IFPMA on behalf of ICH). 


\section{RESEARCH IN CONTEXT}

\section{Evidence before this study}

Morbidity and mortality is increased in patients with schizophrenia and other severe mental disorders as compared to the general population. The reasons, however, are not completely understood. Treatment with antipsychotic drugs might play a role by causing acutely-occurring serious side effects and through the consequences of chronically-persisting side effects. In observational data use of antipsychotics has been associated with several serious physical disorders that may arise from acutely-occurring side effects. However, using observational data it is hard to determine whether antipsychotics actually cause these disorders or whether the association is only mediated by confounding factors.

Randomised controlled trials (RCTs) are considered the best study design to examine causality and in modern RCTs it is mandatory to record ICH-GCP-defined serious adverse events (SAEs). A meta-analysis of SAEs occurring in placebo-controlled RCTs of antipsychotic drugs, therefore, could be highly informative for the question of whether antipsychotics cause serious physical disorders through acutely-occurring side effects. We searched PubMed for metaanalyses on this topic using the broad search string "((serious adverse event) OR SAE) AND (antipsychotic OR neuroleptic)” (last search 21.12.2018), but among 129 hits we found no such analysis.

\section{Added value of this study}

We included 597 studies and 108664 patients across indications and analyzed the occurrence of somatic SAEs with antipsychotics compared to placebo. With the outcome somatic SAEs, we focused on physical side effects. We found evidence that antipsychotics increase somatic SAEs even in relatively short-term trials $((88 \% \leq 3$ month). Elderly, and with weaker evidence children and adolescents, appeared to be at higher risk as compared to adults. 


\section{Implications of all available evidence}

Clinicians should be aware that antipsychotics are potentially toxic drugs and use them carefully

- especially when treating patients that appear particularly vulnerable such as the elderly, and possibly children and adolescents. 


\section{Figure 1: Study selection}

\section{PRISMA diagram of the search process}

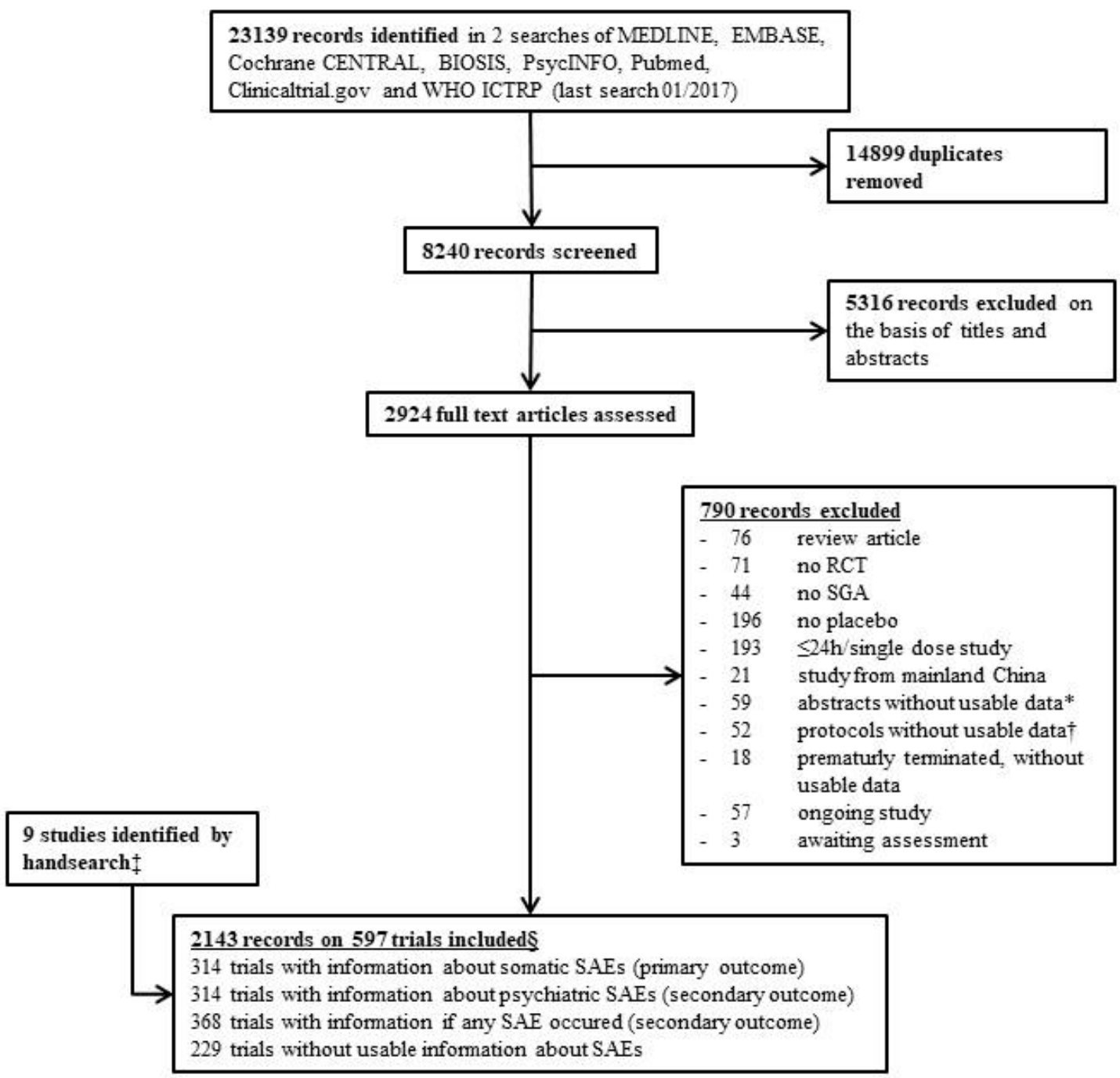

* abstracts without usable data, reporting on pooled data analyses and other posthoc analyses. It is most likely, that these abstracts refer to studies already included in the analysis, but it could not be decided with full certainty

† protocols of clinical trials (all without data), for which the status of the trial is unclear. i.e. it is unclear if they have ever been conducted, if they have been terminated or if their results were not published yet

$\ddagger$ handsearch has been conducted in own database of schizophrenia trials and on the webpages of pharmaceutical companies, the Federal Drug Administration, and the European Medicine Agency

$\S$ in our analysis on mortality based on the same dataset, we included 596 studies only. The reasons is that, after database lock for mortality, we recieved information on SAEs for two studies (252 patients) that were only reported as protocols and thus excluded so far. Moreover one study (335 patients) was identfied as a duplicate to another included study and thus removed. 


\section{TABLES}

\section{Table 1: Results of primary and secondary outcomes}

\begin{tabular}{|c|c|c|c|c|c|c|c|c|c|c|c|c|}
\hline & \multicolumn{2}{|c|}{ Studies } & \multicolumn{3}{|c|}{ Total } & \multicolumn{3}{|c|}{ Drug } & \multicolumn{3}{|c|}{ Placebo } & \multirow{2}{*}{$\begin{array}{c}\text { Results } \\
\text { OR }(95 \% \text { CI) }\end{array}$} \\
\hline $\begin{array}{l}\text { Primary and } \\
\text { secondary } \\
\text { outcomes }\end{array}$ & $\begin{array}{l}\text { Studies } \\
\text { with } \\
\text { data }(K)\end{array}$ & $\begin{array}{c}\text { Studies } \\
\text { with at } \\
\text { least one } \\
\text { event (k) }\end{array}$ & $\begin{array}{l}\text { Patients with at } \\
\text { least one event } \\
(\%) \\
\text { at minimum } \\
\text { at maximum }\end{array}$ & $\begin{array}{l}\text { Patients in } \\
\text { studies } \\
\text { with data } \\
\text { (N) }\end{array}$ & $\begin{array}{l}\text { Patients in } \\
\text { studies } \\
\text { with at } \\
\text { least one } \\
\text { event (n) }\end{array}$ & $\begin{array}{c}\text { Patients with at } \\
\text { least one event } \\
(\%) \\
\text { at minimum } \\
\text { at maximum }\end{array}$ & $\begin{array}{l}\text { Patients in } \\
\text { studies } \\
\text { with data } \\
\text { (N) }\end{array}$ & $\begin{array}{l}\text { Patients in } \\
\text { studies } \\
\text { with at } \\
\text { least one } \\
\text { event (n) }\end{array}$ & $\begin{array}{c}\text { Patients with at } \\
\text { least one event } \\
(\%) \\
\text { at minimum } \\
\text { at maximum }\end{array}$ & $\begin{array}{l}\text { Patients in } \\
\text { studies } \\
\text { with data } \\
\text { (N) }\end{array}$ & $\begin{array}{l}\text { Patients in } \\
\text { studies } \\
\text { with at } \\
\text { least one } \\
\text { event (n) }\end{array}$ & \\
\hline Somatic SAE & 314 & 196 & $\begin{array}{l}1041(1.54 \%) \\
1281(1.89 \%)\end{array}$ & 67642 & 57850 & $\begin{array}{l}698(1.63 \%) \\
862(2.02 \%)\end{array}$ & 42600 & 37073 & $\begin{array}{l}343(1.37 \%) \\
419(1.67 \%)\end{array}$ & 25042 & 20777 & $\begin{array}{l}1.24(1.08,1.42) \\
1.24(1.10,1.41)\end{array}$ \\
\hline Psychiatric SAE & 314 & 186 & $\begin{array}{l}1884(2.79 \%) \\
2082(3.08 \%)\end{array}$ & 67598 & 56381 & $\begin{array}{l}1038(2.43 \%) \\
1161(2.72 \%)\end{array}$ & 42606 & 36307 & $\begin{array}{l}846(3.39 \%) \\
921(3.69 \%)\end{array}$ & 24992 & 20074 & $\begin{array}{l}0.64(0.58,0.71) \\
0.67(0.61,0.73)\end{array}$ \\
\hline Any SAE & 368 & 276 & 4084 (4.55\%) & 89731 & 84999 & 2445 (4.3\%) & 56870 & 54343 & 1639 (4.99\%) & 32861 & 30656 & $0.83(0.77,0.89)$ \\
\hline
\end{tabular}

The number of studies with data $(\mathrm{K})$ includes studies where no event occurred. The proportion of patients with at least one event is with respect to the total number of patients with data on the outcome $(\mathrm{N})$, i.e., including all studies with data $(\mathrm{K})$. OR=odds ratio. $95 \% \mathrm{CI}=95 \%$ confidence interval. 
Table 2: Sensitivity analyses

\begin{tabular}{|c|c|c|c|c|c|c|c|c|c|c|c|c|}
\hline \multirow[b]{2}{*}{$\begin{array}{l}\text { Sensitivity } \\
\text { analyses }\end{array}$} & \multicolumn{2}{|c|}{ Studies } & \multicolumn{3}{|c|}{ Total } & \multicolumn{3}{|c|}{ Drug } & \multicolumn{3}{|c|}{ Placebo } & \multirow{2}{*}{$\begin{array}{c}\text { Results } \\
\text { OR }(95 \% \text { CI })\end{array}$} \\
\hline & $\begin{array}{c}\text { Studies } \\
\text { with } \\
\text { data on } \\
\text { somatic } \\
\text { SAEs } \\
\text { (K) }\end{array}$ & $\begin{array}{c}\text { Studies } \\
\text { with at } \\
\text { least one } \\
\text { somatic } \\
\text { SAE (k) }\end{array}$ & $\begin{array}{c}\text { Patients with at } \\
\text { least one } \\
\text { somatic SAE } \\
(\%) \\
\text { at minimum } \\
\text { at maximum }\end{array}$ & $\begin{array}{c}\text { Patients in } \\
\text { studies } \\
\text { with data } \\
\text { on somatic } \\
\text { SAEs (N) }\end{array}$ & $\begin{array}{l}\text { Patients in } \\
\text { studies } \\
\text { with at } \\
\text { least one } \\
\text { somatic } \\
\text { SAE (n) }\end{array}$ & $\begin{array}{c}\text { Patients with at } \\
\text { least one } \\
\text { somatic SAE } \\
(\%) \\
\text { at minimum } \\
\text { at maximum }\end{array}$ & $\begin{array}{c}\text { Patients in } \\
\text { studies } \\
\text { with data } \\
\text { on somatic } \\
\text { SAEs (N) }\end{array}$ & $\begin{array}{l}\text { Patients in } \\
\text { studies } \\
\text { with at } \\
\text { least one } \\
\text { somatic } \\
\text { SAE (n) }\end{array}$ & $\begin{array}{c}\text { Patients with at } \\
\text { least one } \\
\text { somatic SAE } \\
(\%) \\
\text { at minimum } \\
\text { at maximum }\end{array}$ & $\begin{array}{l}\text { Patients in } \\
\text { studies } \\
\text { with data } \\
\text { on somatic } \\
\text { SAEs (N) }\end{array}$ & $\begin{array}{l}\text { Patients in } \\
\text { studies } \\
\text { with at } \\
\text { least one } \\
\text { somatic } \\
\text { SAE (n) }\end{array}$ & \\
\hline $\begin{array}{l}\text { SAEs during } \\
\text { randomised } \\
\text { phase only (plus } \\
24 \mathrm{~h})\end{array}$ & 162 & 59 & $\begin{array}{l}362(1.69 \%) \\
388(1.81 \%)\end{array}$ & 21459 & 15265 & $\begin{array}{l}266(2.0 \%) \\
285(2.1 \%)\end{array}$ & 13361 & 9956 & $\begin{array}{c}96(1.2 \%) \\
103(1.3 \%)\end{array}$ & 8098 & 5309 & $\begin{array}{c}1.60(1.25,2.04) \\
1.61(1.27,2.04)^{*}\end{array}$ \\
\hline Peto's model & \multirow{4}{*}{314} & \multirow{4}{*}{196} & \multirow{4}{*}{$\begin{array}{l}1041(1.54 \%) \\
1281(1.89 \%)\end{array}$} & \multirow{4}{*}{67642} & \multirow{4}{*}{57850} & \multirow{4}{*}{$\begin{array}{l}698(1.63 \%) \\
862(2.02 \%)\end{array}$} & \multirow{4}{*}{42600} & \multirow{4}{*}{37073} & \multirow{4}{*}{$\begin{array}{l}343(1.37 \%) \\
419(1.67 \%)\end{array}$} & \multirow{4}{*}{25042} & \multirow{4}{*}{20777} & $\begin{array}{c}1.23(1.08,1.41) \\
1.23(1.09,1.39)^{*}\end{array}$ \\
\hline $\begin{array}{c}\text { Bayesian } \\
\text { common-effects } \\
\text { model }\end{array}$ & & & & & & & & & & & & $\begin{array}{c}1.23(1.07,1.40) \\
1.23(1.09,1.40) \dagger\end{array}$ \\
\hline $\begin{array}{c}\text { Bayesian } \\
\text { random-effects } \\
\text { model }\end{array}$ & & & & & & & & & & & & $\begin{array}{c}1.17(1.00,1.36) \\
1.14(0.96,1.33) \dagger\end{array}$ \\
\hline $\begin{array}{c}\text { Correlated beta- } \\
\text { binomial } \\
\text { (Sarmanov) } \\
\text { model }\end{array}$ & & & & & & & & & & & & $\begin{array}{l}1.23(0.98 ; 1.55) \\
1.25(1.00 ; 1.58)\end{array}$ \\
\hline $\begin{array}{c}\text { Treatment- } \\
\text { related SAEs } \\
\text { (SAR, judged by } \\
\text { original } \\
\text { investigators) } \ddagger \\
\end{array}$ & 183 & 37 & $\begin{array}{l}89(0.29 \%) \\
97(0.32 \%)\end{array}$ & 30571 & 12354 & $\begin{array}{l}61(0.32 \%) \\
66(0.34 \%)\end{array}$ & 19148 & 8368 & $\begin{array}{l}28(0.25 \%) \\
31(0.27 \%)\end{array}$ & 11423 & 3986 & $\begin{array}{l}1.29(0.82,2.04) \\
1.27(0.82,1.96)\end{array}$ \\
\hline $\begin{array}{l}\text { Double-blind } \\
\text { studies only }\end{array}$ & 306 & 194 & $\begin{array}{c}1037(1.54 \%) \\
1277(1.9 \%)\end{array}$ & 67272 & 57783 & $\begin{array}{l}695(1.64 \%) \\
859(2.03 \%)\end{array}$ & 42394 & 37038 & $\begin{array}{l}342(1.37 \%) \\
418(1.68 \%)\end{array}$ & 24878 & 20745 & $\begin{array}{l}1.24(1.08,1.42) \\
1.24(1.09,1.40)\end{array}$ \\
\hline
\end{tabular}




\begin{tabular}{|c|c|c|c|c|c|c|c|c|c|c|c|c|}
\hline & $\begin{array}{c}\text { Studies } \\
\text { with } \\
\text { data on } \\
\text { somatic } \\
\text { SAEs } \\
\text { (K) }\end{array}$ & $\begin{array}{c}\text { Studies } \\
\text { with at } \\
\text { least one } \\
\text { somatic } \\
\text { SAE (k) }\end{array}$ & $\begin{array}{c}\text { Patients with at } \\
\text { least one } \\
\text { somatic SAE } \\
\text { (Patients with at } \\
\text { least one } \\
\text { somatic SAE } \\
\text { per } 1000 \\
\text { patient-years) } \\
\text { at minimum } \\
\text { at maximum }\end{array}$ & $\begin{array}{c}\text { Patient- } \\
\text { years in } \\
\text { studies } \\
\text { with data } \\
\text { on somatic } \\
\text { SAEs } \\
\text { (number } \\
\text { of } \\
\text { patients) }\end{array}$ & $\begin{array}{c}\text { Patient- } \\
\text { years in } \\
\text { studies } \\
\text { with at } \\
\text { least one } \\
\text { somatic } \\
\text { SAE } \\
\text { (number } \\
\text { of } \\
\text { patients) }\end{array}$ & $\begin{array}{c}\text { Patients with at } \\
\text { least one } \\
\text { somatic SAE } \\
\text { (Patients with at } \\
\text { least one } \\
\text { somatic SAE } \\
\text { per } 1000 \\
\text { patient-years) } \\
\text { at minimum } \\
\text { at maximum }\end{array}$ & $\begin{array}{c}\text { Patient- } \\
\text { years in } \\
\text { studies } \\
\text { with data } \\
\text { on somatic } \\
\text { SAEs } \\
\text { (number } \\
\text { of } \\
\text { patients) }\end{array}$ & $\begin{array}{c}\text { Patient- } \\
\text { years in } \\
\text { studies } \\
\text { with at } \\
\text { least one } \\
\text { somatic } \\
\text { SAE } \\
\text { (number } \\
\text { of } \\
\text { patients) }\end{array}$ & $\begin{array}{c}\text { Patients with at } \\
\text { least one } \\
\text { somatic SAE } \\
\text { (Patients with at } \\
\text { least one } \\
\text { somatic SAE } \\
\text { per } 1000 \\
\text { patient-years) } \\
\text { at minimum } \\
\text { at maximum }\end{array}$ & $\begin{array}{c}\text { Patient- } \\
\text { years in } \\
\text { studies } \\
\text { with data } \\
\text { on somatic } \\
\text { SAEs } \\
\text { (number } \\
\text { of } \\
\text { patients) }\end{array}$ & $\begin{array}{c}\text { Patient- } \\
\text { years in } \\
\text { studies } \\
\text { with at } \\
\text { least one } \\
\text { somatic } \\
\text { SAE } \\
\text { (number } \\
\text { of } \\
\text { patients) }\end{array}$ & IRR (95\% CI) \\
\hline Incidence rates & 150 & 57 & $\begin{array}{l}359(187) \\
385 \text { (200) }\end{array}$ & $\begin{array}{c}2645 \\
(21533)\end{array}$ & $\begin{array}{c}1921 \\
\text { patient- } \\
\text { years } \\
(15032 \\
\text { patients })\end{array}$ & $\begin{array}{l}264(211) \\
283(227)\end{array}$ & $\begin{array}{c}1641 \\
\text { patient- } \\
\text { years } \\
(13387 \\
\text { patients }) \\
\end{array}$ & $\begin{array}{c}1248 \\
\text { patient- } \\
\text { years } \\
(9843 \\
\text { patients) } \\
\end{array}$ & $\begin{array}{c}95(147) \\
102(152)\end{array}$ & $\begin{array}{c}1007 \\
\text { patient- } \\
\text { years } \\
(8146 \\
\text { patients }) \\
\end{array}$ & $\begin{array}{c}673 \\
\text { patient- } \\
\text { years } \\
\text { (5189 } \\
\text { patients) } \\
\end{array}$ & $\begin{array}{c}1.46(1.08,1.96) \\
1.45(1.09,1.94) \\
\text { (random effects } \\
\text { generalized linear } \\
\text { model)* }\end{array}$ \\
\hline
\end{tabular}

The number of studies with data $(\mathrm{K})$ includes studies where no event occurred. The proportion of patients with at least one event is with respect to the total number of patients with data on the outcome $(\mathrm{N})$, i.e., including all studies with data $(\mathrm{K})$. OR=odds ratio. IRR=incidence rate ratio. 95\% CI=95\% confidence interval. 95\% CrI=95\% credible interval.

\section{$* \mathrm{OR}(95 \% \mathrm{CI})$.}

\section{†OR (95\% CrI)}

$\ddagger 12$ studies provided information about treatment-related somatic SAEs only. Thus, they are included in this sensitivity analysis but not in the primary analysis (appendix: characteristic of included studies). 
$\underline{\text { Table 3: Subgroup analyses }}$

\begin{tabular}{|c|c|c|c|c|c|c|c|c|c|c|c|c|c|}
\hline \multirow[b]{2}{*}{ Subgroup analyses } & \multicolumn{2}{|c|}{ Studies } & \multicolumn{3}{|c|}{ Total } & \multicolumn{3}{|c|}{ Drug } & \multicolumn{3}{|c|}{ Placebo } & \multicolumn{2}{|c|}{ Results } \\
\hline & $\begin{array}{c}\text { Studies } \\
\text { with data } \\
\text { on } \\
\text { somatic } \\
\text { SAEs (K) }\end{array}$ & $\begin{array}{c}\text { Studies } \\
\text { with at } \\
\text { least one } \\
\text { somatic } \\
\text { SAE (k) }\end{array}$ & 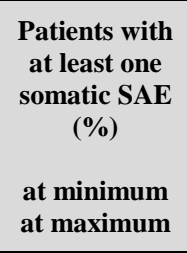 & \begin{tabular}{|c} 
Patients in \\
studies with \\
data on \\
somatic \\
SAEs (N)
\end{tabular} & \begin{tabular}{|c} 
Patients in \\
studies with \\
at least one \\
somatic \\
SAE (n)
\end{tabular} & $\begin{array}{c}\text { Patients with } \\
\text { at least one } \\
\text { somatic SAE } \\
(\%) \\
\text { at minimum } \\
\text { at maximum }\end{array}$ & $\begin{array}{c}\text { Patients in } \\
\text { studies with } \\
\text { data on } \\
\text { somatic } \\
\text { SAEs (N) }\end{array}$ & $\begin{array}{c}\text { Patients in } \\
\text { studies with } \\
\text { at least one } \\
\text { somatic } \\
\text { SAE (n) }\end{array}$ & 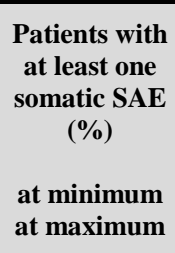 & $\begin{array}{c}\text { Patients in } \\
\text { studies with } \\
\text { data on } \\
\text { somatic } \\
\text { SAEs (N) }\end{array}$ & \begin{tabular}{|} 
Patients in \\
studies with \\
at least one \\
somatic \\
SAE (n)
\end{tabular} & OR $(95 \%$ CI) & $\begin{array}{l}\text { Test for } \\
\text { subgrou } \\
\mathbf{p} \\
\text { differen } \\
\text { ces }\end{array}$ \\
\hline \multicolumn{14}{|l|}{$\begin{array}{c}\text { STUDY } \\
\text { DURATION } \\
\end{array}$} \\
\hline $1<6$ days & 12 & 6 & $\begin{array}{l}10(0.54 \%) \\
10(0.54 \%)\end{array}$ & 1850 & 1400 & $\begin{array}{l}10(0.75 \%) \\
10(0.75 \%)\end{array}$ & 1336 & 1073 & $\begin{array}{l}0(0 \%) \\
0(0 \%)\end{array}$ & 514 & 327 & not estimable & \multirow{3}{*}{$\begin{array}{l}\mathrm{p}>0.99 \\
\mathrm{p}>0.99\end{array}$} \\
\hline 6 days -13 weeks & 264 & 160 & $\begin{array}{c}865(1.5 \%) \\
1066(1.85 \%)\end{array}$ & 57635 & 48861 & $\begin{array}{c}588(1.6 \%) \\
728(1.98 \%) \\
\end{array}$ & 36813 & 31853 & $\begin{array}{l}277(1.33 \%) \\
338(1.62 \%)\end{array}$ & 20822 & 17008 & $\begin{array}{l}1.22(1.05 .1 .42) \\
1.23(1.08 .1 .41)\end{array}$ & \\
\hline$>13$ weeks & 38 & 30 & $\begin{array}{l}166(2.04 \%) \\
205(2.51 \%) \\
\end{array}$ & 8157 & 7589 & $\begin{array}{l}100(2.25 \%) \\
124(2.79 \%)\end{array}$ & 4451 & 4147 & $\begin{array}{l}66(1.78 \%) \\
81(2.19 \%) \\
\end{array}$ & 3706 & 3442 & $\begin{array}{l}1.24(0.90 .1 .70) \\
1.22(0.91 .1 .63)\end{array}$ & \\
\hline \multicolumn{14}{|l|}{ AGE GROUP* } \\
\hline $\begin{array}{l}\text { Children and } \\
\text { adolescents }\end{array}$ & 42 & 23 & $\begin{array}{l}53(0.88 \%) \\
58(0.96 \%)\end{array}$ & 6047 & 4191 & $\begin{array}{l}36(0.96 \%) \\
40(1.07 \%)\end{array}$ & 3731 & 2632 & $\begin{array}{l}17(0.73 \%) \\
18(0.78 \%)\end{array}$ & 2316 & 1559 & $\begin{array}{l}1.49(0.81 .2 .75) \\
1.54(0.85 .2 .77)\end{array}$ & \multirow{3}{*}{$\begin{array}{l}\mathrm{p}=0.05 \\
\mathrm{p}=0.03\end{array}$} \\
\hline Adults & 246 & 153 & $\begin{array}{l}612(1.09 \%) \\
810(1.44 \%)\end{array}$ & 56301 & 48707 & $\begin{array}{l}394(1.11 \%) \\
528(1.48 \%)\end{array}$ & 35585 & 31368 & $\begin{array}{l}218(1.05 \%) \\
282(1.36 \%)\end{array}$ & 20716 & 17339 & $\begin{array}{l}1.09(0.91 .1 .29) \\
1.10(0.95 .1 .28)\end{array}$ & \\
\hline Elderly & 23 & 20 & $\begin{array}{l}376(7.25 \%) \\
413(7.96 \%)\end{array}$ & 5189 & 4952 & $\begin{array}{l}268(8.29 \%) \\
294(9.10 \%)\end{array}$ & 3232 & 3073 & $\begin{array}{l}108(5.52 \%) \\
119(6.08 \%)\end{array}$ & 1957 & 1879 & $\begin{array}{l}1.56(1.22 .1 .98) \\
1.58(1.25 .1 .99)\end{array}$ & \\
\hline \multicolumn{14}{|l|}{$\begin{array}{c}\text { COMBINATIONS } \\
\text { OF DRUGS } \dagger\end{array}$} \\
\hline Monotherapy & 223 & 152 & $\begin{array}{c}891(1.63 \%) \\
1094(2.00 \%)\end{array}$ & 54689 & 47693 & $\begin{array}{l}620(1.75 \%) \\
760(2.15 \%)\end{array}$ & 35350 & 31426 & $\begin{array}{c}271(1.4 \%) \\
334(1.37 \%) \\
\end{array}$ & 19339 & 16267 & $\begin{array}{l}1.30(1.12 .1 .52) \\
1.29(1.12 .1 .47)\end{array}$ & \multirow{2}{*}{$\begin{array}{l}\mathrm{p}=0.06 \\
\mathrm{p}=0.10\end{array}$} \\
\hline Any combination & 78 & 38 & $\begin{array}{l}122(1.02 \%) \\
156(1.31 \%)\end{array}$ & 11928 & 9390 & $\begin{array}{l}62(0.92 \%) \\
83(1.24 \%)\end{array}$ & 6713 & 5270 & $\begin{array}{l}60(1.15 \%) \\
73(1.4 \%)\end{array}$ & 5215 & 4120 & $\begin{array}{l}0.90(0.62 .1 .29) \\
0.96(0.69 .1 .32)\end{array}$ & \\
\hline $\begin{array}{c}\text { Add-on to } \\
\text { antidepressants }\end{array}$ & 34 & 14 & $\begin{array}{l}40(0.66 \%) \\
42(0.69 \%)\end{array}$ & 6088 & 4299 & $\begin{array}{l}21(0.58 \%) \\
21(0.58 \%)\end{array}$ & 3609 & 2547 & $\begin{array}{l}19(0.77 \%) \\
21(0.85 \%)\end{array}$ & 2479 & 1752 & $\begin{array}{l}0.89(0.47 .1 .67) \\
0.79(0.43 .1 .47)\end{array}$ & \multirow{3}{*}{$\begin{array}{l}p=0.90 \\
p=0.97\end{array}$} \\
\hline $\begin{array}{c}\text { Add-on to } \\
\text { antipsychotics }\end{array}$ & 10 & 2 & $\begin{array}{l}2(0.5 \%) \\
2(0.5 \%)\end{array}$ & 403 & 137 & $\begin{array}{l}1(0.49 \%) \\
1(0.49 \%)\end{array}$ & 205 & 67 & $\begin{array}{l}1(0.51 \%) \\
1(0.51 \%)\end{array}$ & 198 & 70 & $\begin{array}{l}1.05(0.06 .17 .23) \\
1.05(0.06 .17 .23)\end{array}$ & \\
\hline $\begin{array}{l}\text { Add-on to mood } \\
\text { stabilizers }\end{array}$ & 24 & 16 & $\begin{array}{c}53(1.23 \%) \\
78(1.8 \%)\end{array}$ & 4323 & 4145 & $\begin{array}{l}24(1.03 \%) \\
39(1.68 \%)\end{array}$ & 2321 & 2230 & $\begin{array}{l}29(1.45 \%) \\
39(1.95 \%)\end{array}$ & 2002 & 1915 & $\begin{array}{l}0.74(0.42 .1 .29) \\
0.86(0.54 .1 .36)\end{array}$ & \\
\hline
\end{tabular}




\begin{tabular}{|c|c|c|c|c|c|c|c|c|c|c|c|c|c|}
\hline $\begin{array}{l}\text { DIAGNOSTIC } \\
\text { CATEGORY }\end{array}$ & & & & & & & & & & & & & \\
\hline Acute agitation & 1 & 0 & $\begin{array}{l}0(0 \%) \\
0(0 \%)\end{array}$ & 120 & 0 & $\begin{array}{l}0(0 \%) \\
0(0 \%)\end{array}$ & 60 & 0 & $\begin{array}{l}0(0 \%) \\
0(0 \%)\end{array}$ & 60 & 0 & not estimable & \multirow{17}{*}{$\begin{array}{l}\mathrm{p}=0.43 \\
\mathrm{p}=0.24\end{array}$} \\
\hline $\begin{array}{c}\text { ADHD or } \\
\text { disruptive } \\
\text { behaviour disorder } \\
\end{array}$ & 6 & 3 & $\begin{array}{l}14(1.75 \%) \\
14(1.75 \%)\end{array}$ & 800 & 495 & $\begin{array}{l}6(1.51 \%) \\
6(1.51 \%)\end{array}$ & 398 & 250 & $\begin{array}{l}8(1.99 \%) \\
8(1.99 \%)\end{array}$ & 402 & 245 & $\begin{array}{l}0.71(0.24 .2 .10) \\
0.71(0.24 .2 .10)\end{array}$ & \\
\hline Anorexia nervosa & 3 & 1 & $\begin{array}{l}2(2.53 \%) \\
2(2.53 \%)\end{array}$ & 79 & 15 & $\begin{array}{l}2(5.56 \%) \\
2(5.56 \%)\end{array}$ & 36 & 6 & $\begin{array}{l}0(0 \%) \\
0(0 \%)\end{array}$ & 43 & 9 & $\begin{array}{l}10.56(0.41 .268 .69) \\
10.56(0.41 .268 .69)\end{array}$ & \\
\hline Anxiety disorder & 9 & 3 & $\begin{array}{l}13(0.69 \%) \\
13(0.69 \%)\end{array}$ & 1874 & 889 & $\begin{array}{l}5(0.53 \%) \\
5(0.53 \%)\end{array}$ & 948 & 445 & $\begin{array}{l}8(0.86 \%) \\
8(0.86 \%)\end{array}$ & 926 & 444 & $\begin{array}{l}0.61(0.19 .1 .91) \\
0.61(0.19 .1 .91)\end{array}$ & \\
\hline $\begin{array}{c}\text { Autism or pervasive } \\
\text { developmental } \\
\text { disorder }\end{array}$ & 10 & 6 & $\begin{array}{l}11(1.11 \%) \\
11(1.11 \%)\end{array}$ & 991 & 680 & $\begin{array}{l}7(1.19 \%) \\
7(1.19 \%)\end{array}$ & 589 & 424 & $\begin{array}{l}4(1.00 \%) \\
4(1.00 \%)\end{array}$ & 402 & 256 & $\begin{array}{l}1.25(0.33 .4 .65) \\
1.25(0.33 .4 .65)\end{array}$ & \\
\hline Bipolar disorder & 81 & 61 & $\begin{array}{l}225(1.11 \%) \\
304(1.5 \%)\end{array}$ & 20214 & 18748 & $\begin{array}{c}145(1.2 \%) \\
196(1.62 \%)\end{array}$ & 12089 & 11251 & $\begin{array}{l}80(0.98 \%) \\
108(1.33 \%)\end{array}$ & 8125 & 7497 & $\begin{array}{l}1.29(0.97 .1 .71) \\
1.31(1.03 .1 .68)\end{array}$ & \\
\hline $\begin{array}{c}\text { Borderline } \\
\text { personality disorder }\end{array}$ & 4 & 2 & $\begin{array}{c}6(0.67 \%) \\
13(1.44 \%)\end{array}$ & 900 & 765 & $\begin{array}{l}4(0.74 \%) \\
8(1.48 \%)\end{array}$ & 539 & 453 & $\begin{array}{l}2(0.55 \%) \\
5(1.39 \%)\end{array}$ & 361 & 312 & $\begin{array}{l}1.32(0.23 .7 .53) \\
1.03(0.33 .3 .22)\end{array}$ & \\
\hline $\begin{array}{c}\text { Chemotherapy- } \\
\text { induced nausea and } \\
\text { vomiting }\end{array}$ & 1 & 0 & $\begin{array}{l}0(0 \%) \\
0(0 \%)\end{array}$ & 44 & 0 & $\begin{array}{l}0(0 \%) \\
0(0 \%)\end{array}$ & 22 & 0 & $\begin{array}{l}0(0 \%) \\
0(0 \%)\end{array}$ & 22 & 0 & not estimable & \\
\hline Dementia & 15 & 14 & $\begin{array}{l}351 \text { (8.69\%) } \\
382(9.75 \%)\end{array}$ & 3916 & 3712 & $\begin{array}{c}253(9.86 \%) \\
273(10.64 \%)\end{array}$ & 2566 & 2429 & $\begin{array}{c}98(7.26 \%) \\
109(8.07 \%)\end{array}$ & 1350 & 1283 & $\begin{array}{l}1.59(1.23 .2 .04) \\
1.56(1.23 .1 .99)\end{array}$ & \\
\hline Drug abuse & 18 & 8 & $\begin{array}{l}35(2.55 \%) \\
36(2.62 \%) \\
\end{array}$ & 1375 & 880 & $\begin{array}{l}19(2.64 \%) \\
20(2.78 \%) \\
\end{array}$ & 719 & 437 & $\begin{array}{l}16(2.44 \%) \\
16(2.44 \%) \\
\end{array}$ & 656 & 443 & $\begin{array}{l}1.21(0.61 .2 .40) \\
1.28(0.65 .2 .51)\end{array}$ & \\
\hline Dysthymia & 1 & 0 & $\begin{array}{l}0(0 \%) \\
0(0 \%)\end{array}$ & 39 & 0 & $\begin{array}{l}0(0 \%) \\
0(0 \%)\end{array}$ & 20 & 0 & $\begin{array}{l}0(0 \%) \\
0(0 \%)\end{array}$ & 19 & 0 & not estimable & \\
\hline Fibromyalgia & 1 & 0 & $\begin{array}{l}0(0 \%) \\
0(0 \%)\end{array}$ & 51 & 0 & $\begin{array}{l}0(0 \%) \\
0(0 \%)\end{array}$ & 25 & 0 & $\begin{array}{l}0(0 \%) \\
0(0 \%)\end{array}$ & 26 & 0 & not estimable & \\
\hline Gambling addiction & 2 & 0 & $\begin{array}{l}0(0 \%) \\
0(0 \%) \\
\end{array}$ & 63 & 0 & $\begin{array}{l}0(0 \%) \\
0(0 \%)\end{array}$ & 30 & 0 & $\begin{array}{l}0(0 \%) \\
0(0 \%)\end{array}$ & 33 & 0 & not estimable & \\
\hline Healthy subjects & 12 & 2 & $\begin{array}{l}3(0.81 \%) \\
3(0.81 \%)\end{array}$ & 369 & 80 & $\begin{array}{l}2(0.88 \%) \\
2(0.88 \%)\end{array}$ & 227 & 52 & $\begin{array}{l}1(0.7 \%) \\
1(0.7 \%)\end{array}$ & 142 & 28 & $\begin{array}{l}1.08(0.10 .11 .84) \\
1.08(0.10 .11 .84)\end{array}$ & \\
\hline $\begin{array}{l}\text { Major depressive } \\
\text { disorder }\end{array}$ & 28 & 15 & $\begin{array}{l}40(0.56 \%) \\
42(0.58 \%)\end{array}$ & 7184 & 5703 & $\begin{array}{l}24(0.55 \%) \\
24(0.55 \%)\end{array}$ & 4356 & 3457 & $\begin{array}{l}16(0.57 \%) \\
18(0.64 \%)\end{array}$ & 2828 & 2246 & $\begin{array}{l}1.05(0.55 .2 .00) \\
0.92(0.49 .1 .73)\end{array}$ & \\
\hline $\begin{array}{c}\text { Obsessive } \\
\text { compulsive disorder }\end{array}$ & 6 & 1 & $\begin{array}{l}4(1.47 \%) \\
4(1.47 \%)\end{array}$ & 272 & 40 & $\begin{array}{l}1(0.68 \%) \\
1(0.68 \%)\end{array}$ & 147 & 20 & $\begin{array}{l}3(2.4 \%) \\
3(2.4 \%)\end{array}$ & 125 & 20 & $\begin{array}{l}0.30(0.03 .3 .15) \\
0.30(0.03 .3 .15)\end{array}$ & \\
\hline Parkinson's disease & 3 & 3 & $\begin{array}{l}12(6.56 \%) \\
18(9.84 \%)\end{array}$ & 183 & 183 & $\begin{array}{c}9(8.65 \%) \\
15(14.42 \%)\end{array}$ & 104 & 104 & $\begin{array}{l}3(3.8 \%) \\
3(3.8 \%)\end{array}$ & 79 & 79 & $\begin{array}{l}2.69(0.69 .10 .52) \\
4.21(1.15 .15 .37)\end{array}$ & \\
\hline
\end{tabular}




\begin{tabular}{|c|c|c|c|c|c|c|c|c|c|c|c|c|c|}
\hline $\begin{array}{l}\text { Post-traumatic } \\
\text { stress disorder }\end{array}$ & 6 & 3 & $\begin{array}{l}19(4.42 \%) \\
19(4.42 \%)\end{array}$ & 430 & 376 & $\begin{array}{l}10(4.67 \%) \\
10(4.67 \%)\end{array}$ & 214 & 187 & $\begin{array}{l}9(4.17 \%) \\
9(4.17 \%)\end{array}$ & 216 & 189 & $\begin{array}{l}1.13(0.45 .2 .83) \\
1.13(0.45 .2 .83)\end{array}$ & \\
\hline Schizophrenia & 100 & 73 & $\begin{array}{l}303(1.07 \%) \\
417(1.48 \%) \\
\end{array}$ & 28252 & 25149 & $\begin{array}{l}208(1.08 \%) \\
290(1.51 \%) \\
\end{array}$ & 19202 & 17469 & $\begin{array}{c}95(1.05 \%) \\
127(1.40 \%) \\
\end{array}$ & 9050 & 7681 & $\begin{array}{l}0.99(0.77 .1 .28) \\
1.02(0.82 .1 .27) \\
\end{array}$ & \\
\hline Stuttering & 2 & 0 & $\begin{array}{l}0(0 \%) \\
0(0 \%) \\
\end{array}$ & 40 & 0 & $\begin{array}{l}0(0 \%) \\
0(0 \%) \\
\end{array}$ & 20 & 0 & $\begin{array}{l}0(0 \%) \\
0(0 \%) \\
\end{array}$ & 20 & 0 & not estimable & \\
\hline Tourette syndrome & 5 & 1 & $\begin{array}{l}3(0.67 \%) \\
3(0.67 \%)\end{array}$ & 446 & 135 & $\begin{array}{l}3(1.04 \%) \\
3(1.04 \%)\end{array}$ & 289 & 90 & $\begin{array}{l}0(0 \%) \\
0(0 \%)\end{array}$ & 157 & 45 & $\begin{array}{l}3.64(0.18 .72 .01) \\
3.64(0.18 .72 .01)\end{array}$ & \\
\hline \multicolumn{14}{|l|}{$\begin{array}{l}\text { ANTIPSYCHOTIC } \\
\text { SUBSTANCE } \ddagger\end{array}$} \\
\hline Amisulpride & 7 & 0 & $\begin{array}{l}0(0 \%) \\
0(0 \%)\end{array}$ & 250 & 0 & $\begin{array}{l}0(0 \%) \\
0(0 \%)\end{array}$ & 137 & 0 & $\begin{array}{l}0(0 \%) \\
0(0 \%)\end{array}$ & 113 & 0 & not estimable & \multirow{14}{*}{$\begin{array}{l}\mathrm{p}=0.87 \\
\mathrm{p}=0.93\end{array}$} \\
\hline Aripiprazole & 59 & 37 & $\begin{array}{l}163(1.37 \%) \\
189(1.58 \%)\end{array}$ & 11926 & 10439 & $\begin{array}{l}101(1.46 \%) \\
115(1.66 \%)\end{array}$ & 6925 & 6068 & $\begin{array}{l}62(1.24 \%) \\
74(1.48 \%)\end{array}$ & 5001 & 4371 & $\begin{array}{l}1.35(0.97 .1 .86) \\
1.28(0.95 .1 .73)\end{array}$ & \\
\hline Asenapine & 16 & 13 & $\begin{array}{l}44(0.96 \%) \\
79(1.72 \%)\end{array}$ & 4596 & 4027 & $\begin{array}{l}26(0.92 \%) \\
45(1.59 \%)\end{array}$ & 2836 & 2451 & $\begin{array}{l}18(1.02 \%) \\
34(1.93 \%)\end{array}$ & 1760 & 1576 & $\begin{array}{l}0.92(0.50 .1 .58) \\
0.93(0.60 .1 .46)\end{array}$ & \\
\hline Brexpiprazole & 9 & 6 & $\begin{array}{l}21(0.59 \%) \\
21(0.59 \%)\end{array}$ & 3534 & 2827 & $\begin{array}{l}16(0.67 \%) \\
16(0.67 \%)\end{array}$ & 2375 & 1863 & $\begin{array}{l}5(0.43 \%) \\
5(0.43 \%)\end{array}$ & 1159 & 964 & $\begin{array}{l}1.75(0.63 .4 .84) \\
1.75(0.63 .4 .84)\end{array}$ & \\
\hline Cariprazine & 4 & 2 & $\begin{array}{l}8(0.41 \%) \\
8(0.41 \%)\end{array}$ & 1971 & 822 & $\begin{array}{l}5(0.39 \%) \\
5(0.39 \%)\end{array}$ & 1273 & 554 & $\begin{array}{l}3(0.43 \%) \\
3(0.43 \%)\end{array}$ & 698 & 268 & $\begin{array}{l}0.89(0.21 .3 .70) \\
0.89(0.21 .3 .70)\end{array}$ & \\
\hline Chlorpromazine & 1 & 1 & $\begin{array}{l}1(0.94 \%) \\
1(0.94 \%)\end{array}$ & 106 & 106 & $\begin{array}{l}1(1.89 \%) \\
1(1.89 \%)\end{array}$ & 53 & 53 & $\begin{array}{l}0(0 \%) \\
0(0 \%)\end{array}$ & 53 & 53 & not estimable & \\
\hline Haloperidol & 17 & 15 & $\begin{array}{c}90(2.79 \%) \\
105(3.26 \%)\end{array}$ & 3225 & 3071 & $\begin{array}{l}52(3.14 \%) \\
64(3.86 \%)\end{array}$ & 1658 & 1584 & $\begin{array}{l}38(2.43 \%) \\
41(2.62 \%)\end{array}$ & 1567 & 1487 & $\begin{array}{l}1.39(0.89 .2 .15) \\
1.61(1.07 .2 .43)\end{array}$ & \\
\hline Iloperidone & 5 & 4 & $\begin{array}{l}19(0.96 \%) \\
43(2.17 \%)\end{array}$ & 1984 & 1964 & $\begin{array}{l}12(0.87 \%) \\
30(2.18 \%)\end{array}$ & 1379 & 1369 & $\begin{array}{c}7(1.16 \%) \\
13(2.15 \%)\end{array}$ & 605 & 595 & $\begin{array}{l}0.74(0.29 .1 .90) \\
0.99(0.51 .1 .93)\end{array}$ & \\
\hline Lurasidone & 14 & 12 & $\begin{array}{l}37(0.84 \%) \\
45(1.02 \%)\end{array}$ & 4423 & 4065 & $\begin{array}{l}21(0.75 \%) \\
28(0.99 \%)\end{array}$ & 2818 & 2610 & $\begin{array}{c}16(1 \%) \\
17(1.06 \%)\end{array}$ & 1605 & 1455 & $\begin{array}{l}0.81(0.41 .1 .59) \\
1.00(0.54 .1 .87)\end{array}$ & \\
\hline Olanzapine & 68 & 40 & $\begin{array}{l}248(2.07 \%) \\
310(2.58 \%)\end{array}$ & 12004 & 9999 & $\begin{array}{c}178(2.5 \%) \\
215(3.03 \%)\end{array}$ & 7106 & 6101 & $\begin{array}{l}70(1.43 \%) \\
95(1.94 \%)\end{array}$ & 4898 & 3898 & $\begin{array}{l}1.46(1.09 .1 .96) \\
1.35(1.04 .1 .74)\end{array}$ & \\
\hline Paliperidone & 27 & 21 & $\begin{array}{c}97(1.28 \%) \\
130(1.71 \%)\end{array}$ & 7590 & 7122 & $\begin{array}{l}64(1.32 \%) \\
89(1.83 \%)\end{array}$ & 4864 & 4592 & $\begin{array}{c}33(1.21 \%) \\
41(1.5 \%)\end{array}$ & 2726 & 2530 & $\begin{array}{l}1.09(0.71 .1 .68) \\
1.23(0.84 .1 .80)\end{array}$ & \\
\hline Quetiapine & 53 & 27 & $\begin{array}{l}106(1.23 \%) \\
109(1.27 \%)\end{array}$ & 8597 & 6189 & $\begin{array}{l}59(1.21 \%) \\
60(1.23 \%)\end{array}$ & 4886 & 3651 & $\begin{array}{l}47(1.27 \%) \\
49(1.32 \%)\end{array}$ & 3711 & 2538 & $\begin{array}{l}1.02(0.68 .1 .53) \\
1.00(0.67 .1 .49)\end{array}$ & \\
\hline Risperidone & 55 & 38 & $\begin{array}{l}245(2.88 \%) \\
288(3.38 \%)\end{array}$ & 8513 & 7280 & $\begin{array}{l}145(3.17 \%) \\
170(3.71 \%)\end{array}$ & 4581 & 3971 & $\begin{array}{c}100(2.54 \%) \\
118(3 \%)\end{array}$ & 3932 & 3309 & $\begin{array}{l}1.32(1.02 .1 .73) \\
1.33(1.04 .1 .70)\end{array}$ & \\
\hline Ziprasidone & 18 & 10 & $\begin{array}{l}25(0.95 \%) \\
32(1.21 \%)\end{array}$ & 2645 & 2431 & $\begin{array}{l}14(0.94 \%) \\
20(1.35 \%)\end{array}$ & 1484 & 1380 & $\begin{array}{l}11(0.95 \%) \\
12(1.03 \%)\end{array}$ & 1161 & 1051 & $\begin{array}{l}0.96(0.41 .2 .24) \\
1.22(0.57 .2 .64)\end{array}$ & \\
\hline
\end{tabular}




\begin{tabular}{|c|c|c|c|c|c|c|c|c|c|c|c|c|c|}
\hline Zotepine & 3 & 2 & $\begin{array}{l}5(1.6 \%) \\
5(1.6 \%)\end{array}$ & 312 & 227 & $\begin{array}{l}3(1.94 \%) \\
3(1.94 \%)\end{array}$ & 155 & 116 & $\begin{array}{l}2(1.27 \%) \\
2(1.27 \%)\end{array}$ & 157 & 111 & $\begin{array}{l}1.43(0.24 .8 .54) \\
1.43 \quad 0.24 .8 .54)\end{array}$ & \\
\hline \multicolumn{14}{|l|}{ FGA/SGAף } \\
\hline FGA & 18 & 16 & $\begin{array}{c}91(2.73 \%) \\
106(3.18 \%)\end{array}$ & 3331 & 3177 & $\begin{array}{l}53(3.1 \%) \\
65(3.8 \%)\end{array}$ & 1711 & 1637 & $\begin{array}{l}38(2.37 \%) \\
41(2.53 \%)\end{array}$ & 1620 & 1540 & $\begin{array}{l}1.42(0.91 ; 2.19) \\
1.64(1.09 ; 2.47)\end{array}$ & \multirow{2}{*}{$\begin{array}{l}\mathrm{p}=0.55 \\
\mathrm{p}=0.19\end{array}$} \\
\hline SGA & 313 & 194 & $\begin{array}{c}988(1.5 \%) \\
1216(1.85 \%)\end{array}$ & 65896 & 55725 & $\begin{array}{l}645 \text { (1.58\%) } \\
797 \text { (1.95\%) }\end{array}$ & 40872 & 35090 & $\begin{array}{l}343 \text { (1.37\%) } \\
419(1.67 \%)\end{array}$ & 25024 & 20635 & $\begin{array}{l}1.23(1.07 ; 1.41) \\
1.23(1.08 ; 1.39)\end{array}$ & \\
\hline \multicolumn{14}{|l|}{ SPONSORSHIP § } \\
\hline $\begin{array}{c}\text { Sponsored by } \\
\text { pharmaceutical } \\
\text { company }\end{array}$ & 263 & 174 & $\begin{array}{l}895(1.52 \%) \\
1105 / 1.87 \%)\end{array}$ & 59066 & 50694 & $\begin{array}{c}574(1.6 \%) \\
709(1.97 \%)\end{array}$ & 35984 & 31159 & $\begin{array}{l}321(1.39 \%) \\
396(1.72 \%)\end{array}$ & 23082 & 19535 & $\begin{array}{l}1.24(1.08 ; 1.44) \\
1.24(1.09 ; 1.41]\end{array}$ & \multirow{2}{*}{$\begin{array}{l}\mathrm{p}=0.73 \\
\mathrm{p}=0.81\end{array}$} \\
\hline $\begin{array}{c}\text { Independent from } \\
\text { pharmaceutical } \\
\text { company }\end{array}$ & 41 & 18 & $\begin{array}{c}46(1.2 \%) \\
49(1.28 \%)\end{array}$ & 3819 & 2247 & $\begin{array}{l}26(1.28 \%) \\
28(1.37 \%)\end{array}$ & 2039 & 1224 & $\begin{array}{l}20(1.12 \%) \\
21(1.18 \%)\end{array}$ & 1780 & 1023 & $\begin{array}{l}1.12(0.61 ; 2.03) \\
1.15(0.64 ; 2.07)\end{array}$ & \\
\hline
\end{tabular}

The number of studies with data $(\mathrm{K})$ includes studies where no event occurred. The proportion of patients with at least one event is with respect to the total number of patients with data on the outcome $(\mathrm{N})$, i.e., including all studies with data $(\mathrm{K})$. OR=odds ratio. $95 \% \mathrm{CI}=95 \%$ confidence interval.

* 3 studies (all without events) included patients of different age groups ( $\mathrm{N}=105)$.

† In an additional 13 studies (6 with events) with 1025 patients (767 patients in studies with events) with 28-31 events, antipsychotics were combined with illegal drugs. These studies were not included in this analysis.

$\ddagger$ No data on somatic SAEs was found for the antipsychotics clozapine and sertindole. Two studies allowed several second-generation antipsychotic drugs (79 patients on drug, 70 patients on placebo). Chlorpromazine and haloperidol are included because these first generation antipsychotics were used as additional active comparators in placebocontrolled studies of second-generation antipsychotics. Of note, this subgroup-analysis did not account for multiple uses of placebo-groups in multi-arm studies.

$\S$ For 10 studies sponsorship was unclear. 18 drug arms used as active comparators in industry-sponsored trials were excluded.

I One study (Borlido 2016) was not included, because both, SGAs and FGAs, were used in the drug arm. We additionally meta-analysed head to head comparisons of FGAs and SGAs based on studies using FGAs as active comparators (appendix: additional analyses; minimum estimate OR 1.15 (95\%CI 0.77. 1.70); maximum estimate OR 1.33 (95\%CI $0.92,1.90)$. 


\section{Table 4: Meta-regression analyses}

\begin{tabular}{|c|c|c|c|c|c|c|c|c|c|c|c|c|}
\hline & \multicolumn{2}{|c|}{ Studies } & \multicolumn{3}{|c|}{ Total } & \multicolumn{3}{|c|}{ Drug } & \multicolumn{3}{|c|}{ Placebo } & \multirow{2}{*}{$\begin{array}{l}\text { Results } \\
\\
\text { Regression } \\
\text { coefficient } \\
\text { (95\% CrI) }\end{array}$} \\
\hline Meta-regression & $\begin{array}{c}\text { Studies } \\
\text { with data } \\
\text { on } \\
\text { somatic } \\
\text { SAEs (K) }\end{array}$ & $\begin{array}{c}\text { Studies } \\
\text { with at } \\
\text { least one } \\
\text { somatic } \\
\text { SAE (k) }\end{array}$ & $\begin{array}{l}\text { Patients with at } \\
\text { least one somatic } \\
\text { SAE (\%) } \\
\text { at minimum } \\
\text { at maximum }\end{array}$ & $\begin{array}{c}\text { Patients in } \\
\text { studies with } \\
\text { data on } \\
\text { somatic } \\
\text { SAEs (N) }\end{array}$ & $\begin{array}{c}\text { Patients in } \\
\text { studies with } \\
\text { at least one } \\
\text { somatic } \\
\text { SAE (n) }\end{array}$ & $\begin{array}{l}\text { Patients with at } \\
\text { least one somatic } \\
\text { SAE (\%) } \\
\text { at minimum } \\
\text { at maximum }\end{array}$ & $\begin{array}{l}\text { Patients in } \\
\text { studies with } \\
\text { data on } \\
\text { somatic } \\
\text { SAEs (N) }\end{array}$ & \begin{tabular}{|c|} 
Patients in \\
studies with \\
at least one \\
somatic \\
SAE (n)
\end{tabular} & $\begin{array}{l}\text { Patients with at } \\
\text { least one somatic } \\
\text { SAE (\%) } \\
\text { at minimum } \\
\text { at maximum }\end{array}$ & $\begin{array}{c}\text { Patients in } \\
\text { studies with } \\
\text { data on } \\
\text { somatic } \\
\text { SAEs (N) }\end{array}$ & $\begin{array}{c}\text { Patients in } \\
\text { studies with } \\
\text { at least one } \\
\text { somatic } \\
\text { SAE (n) }\end{array}$ & \\
\hline $\begin{array}{c}\text { ANTIPSYCHOTIC } \\
\text { DOSE }\end{array}$ & 186 & 118 & $\begin{array}{l}450(1.02 \%) \\
583(1.33 \%)\end{array}$ & 43947 & 37194 & $\begin{array}{l}289(1.06 \%) \\
375(1.38 \%)\end{array}$ & 27262 & 23489 & $\begin{array}{l}161(0.97 \%) \\
208(1.25 \%)\end{array}$ & 16680 & 13705 & $\begin{array}{c}0.017 \\
(-0.003,0.037) \\
0.023 \\
(0.004,0.043)^{*}\end{array}$ \\
\hline $\begin{array}{l}\text { PROPORTION OF } \\
\text { WOMEN IN } \\
\text { STUDY }\end{array}$ & 292 & 188 & $\begin{array}{c}972 \\
1208\end{array}$ & 66445 & 57043 & $\begin{array}{l}655 \\
816\end{array}$ & 41935 & 20436 & $\begin{array}{l}317 \\
392\end{array}$ & 24510 & 36607 & $\begin{array}{c}0.30 \\
(-0.40,0.99) \\
0.12 \\
(-0.63,0.84) \dagger\end{array}$ \\
\hline
\end{tabular}

The number of studies with data $(\mathrm{K})$ includes studies where no event occurred. The proportion of patients with at least one event is with respect to the total number of patients with data on the outcome $(\mathrm{N})$, i.e., including all studies with data $(\mathrm{K})$. OR=odds ratio. $95 \% \mathrm{CI}=95 \%$ confidence interval.

*Regression coefficient for increase in logOR (logarithmic OR) per mg olanzapine equivalent, corresponding to an OR (minimum/maximum estimate) of 0.96/0.90 for studies

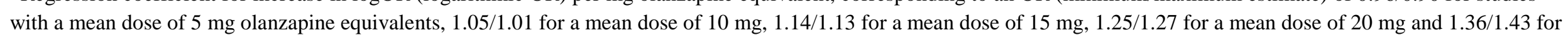
a mean dose of $25 \mathrm{mg}$.

†Regression coefficient for increase in logOR (logarithmic OR) per 1\% increase in women, corresponding to an OR (minimum/maximum estimate) of $1.13 / 1.13$ for study populations with $25 \%$ female patients, $1.22 / 1.16$ for those with $50 \%$ female patients and 1.31/1.20 for those with $75 \%$ female patients. 
Table 5: Somatic SAEs grouped by MedDRA System-Organ-Class

\begin{tabular}{|c|c|c|c|c|c|c|c|c|c|c|c|c|}
\hline & \multicolumn{2}{|c|}{ Studies } & \multicolumn{3}{|c|}{ Total } & \multicolumn{3}{|c|}{ Drug } & \multicolumn{3}{|c|}{ Placebo } & \multirow{2}{*}{$\begin{array}{c}\text { Results } \\
\text { OR }(95 \% \text { CI) }\end{array}$} \\
\hline $\begin{array}{l}\text { System-Organ- } \\
\text { Class (SOC) }\end{array}$ & $\begin{array}{l}\text { Studies } \\
\text { with } \\
\text { data (K) }\end{array}$ & $\begin{array}{c}\text { Studies } \\
\text { with at } \\
\text { least one } \\
\text { event (k) }\end{array}$ & $\begin{array}{l}\text { Patients with at } \\
\text { least one event } \\
(\%) \\
\text { at minimum* } \\
\text { at maximum }\end{array}$ & $\begin{array}{l}\text { Patients in } \\
\text { studies } \\
\text { with data } \\
\text { (N) }\end{array}$ & $\begin{array}{l}\text { Patients in } \\
\text { studies } \\
\text { with at } \\
\text { least one } \\
\text { event (n) }\end{array}$ & $\begin{array}{c}\text { Patients with at } \\
\text { least one event } \\
(\%) \\
\text { at minimum } \\
\text { at maximum }\end{array}$ & $\begin{array}{l}\text { Patients in } \\
\text { studies } \\
\text { with data } \\
\text { (N) }\end{array}$ & $\begin{array}{l}\text { Patients in } \\
\text { studies } \\
\text { with at } \\
\text { least one } \\
\text { event (n) }\end{array}$ & $\begin{array}{l}\text { Patients with at } \\
\text { least one event } \\
(\%) \\
\text { at minimum } \\
\text { at maximum }\end{array}$ & $\begin{array}{l}\text { Patients in } \\
\text { studies } \\
\text { with data } \\
\text { (N) }\end{array}$ & $\begin{array}{l}\text { Patients in } \\
\text { studies } \\
\text { with at } \\
\text { least one } \\
\text { event (n) }\end{array}$ & \\
\hline $\begin{array}{c}\text { Blood and } \\
\text { lymphatic } \\
\text { system disorders }\end{array}$ & 314 & 12 & $\begin{array}{l}16(0.02 \%) \\
21(0.03 \%)\end{array}$ & 67642 & 4219 & $\begin{array}{l}11(0.03 \%) \\
13(0.03 \%)\end{array}$ & 42600 & 2839 & $\begin{array}{l}5(0.02 \%) \\
8(0.03 \%)\end{array}$ & 25042 & 1380 & $\begin{array}{l}1.17(0.37 ; 3.75) \\
0.95(0.36 ; 2.52)\end{array}$ \\
\hline $\begin{array}{l}\text { Cardiac } \\
\text { disorders }\end{array}$ & 314 & 54 & $\begin{array}{c}92(0.14 \%) \\
144(0.21 \%)\end{array}$ & 67642 & 19642 & $\begin{array}{l}60(0.14 \%) \\
98(0.23 \%)\end{array}$ & 42600 & 13030 & $\begin{array}{l}32(0.13 \%) \\
46(0.18 \%)\end{array}$ & 25042 & 6612 & $\begin{array}{l}1.03(0.66 ; 1.61) \\
1.22(0.85 ; 1.75)\end{array}$ \\
\hline $\begin{array}{l}\text { Congenital, } \\
\text { familial and } \\
\text { genetic } \\
\text { disorders }\end{array}$ & 314 & 1 & $\begin{array}{l}1(0 \%) \\
1(0 \%)\end{array}$ & 67642 & 182 & $\begin{array}{l}1(0 \%) \\
1(0 \%)\end{array}$ & 42600 & 120 & $\begin{array}{l}0(0 \%) \\
0(0 \%)\end{array}$ & 25042 & 62 & not estimable \\
\hline $\begin{array}{l}\text { Ear and } \\
\text { labyrinth } \\
\text { disorders }\end{array}$ & 314 & 7 & $\begin{array}{l}7(0.01 \%) \\
7(0.01 \%)\end{array}$ & 67642 & 2910 & $\begin{array}{l}3(0.01 \%) \\
3(0.01 \%)\end{array}$ & 42600 & 2017 & $\begin{array}{l}4(0.02 \%) \\
4(0.02 \%)\end{array}$ & 25042 & 893 & $\begin{array}{l}0.28(0.05 ; 1.46) \\
0.28(0.05 ; 1.46)\end{array}$ \\
\hline Eye disorders & 314 & 5 & $\begin{array}{l}7(0.01 \%) \\
7(0.01 \%)\end{array}$ & 67642 & 1548 & $\begin{array}{l}4(0.01 \%) \\
4(0.01 \%)\end{array}$ & 42600 & 842 & $\begin{array}{l}3(0.01 \%) \\
3(0.01 \%)\end{array}$ & 25042 & 706 & $\begin{array}{l}1.19(0.26 ; 5.48) \\
1.19(0.26 ; 5.48)\end{array}$ \\
\hline $\begin{array}{l}\text { Gastrointestinal } \\
\text { disorders }\end{array}$ & 314 & 64 & $\begin{array}{c}79(0.12 \%) \\
108(0.16 \%)\end{array}$ & 67642 & 23151 & $\begin{array}{l}51(0.12 \%) \\
69(0.16 \%)\end{array}$ & 42600 & 15078 & $\begin{array}{l}28(0.11 \%) \\
39(0.16 \%)\end{array}$ & 25042 & 8073 & $\begin{array}{l}1.08(0.67 ; 1.74) \\
1.10(0.73 ; 1.66)\end{array}$ \\
\hline $\begin{array}{c}\text { General } \\
\text { disorders and } \\
\text { administration } \\
\text { site conditions }\end{array}$ & 314 & 63 & $\begin{array}{c}85(0.13 \%) \\
109(0.16 \%)\end{array}$ & 67642 & 21860 & $\begin{array}{l}54(0.13 \%) \\
68(0.16 \%)\end{array}$ & 42600 & 13953 & $\begin{array}{l}31(0.12 \%) \\
41(0.16 \%)\end{array}$ & 25042 & 7907 & $\begin{array}{l}1.11(0.70 ; 1.76) \\
1.05(0.70 ; 1.57)\end{array}$ \\
\hline
\end{tabular}




\begin{tabular}{|c|c|c|c|c|c|c|c|c|c|c|c|c|}
\hline $\begin{array}{l}\text { Hepatobiliary } \\
\text { disorders }\end{array}$ & 314 & 21 & $\begin{array}{l}22(0.03 \%) \\
23(0.03 \%)\end{array}$ & 67642 & 8850 & $\begin{array}{l}15(0.04 \%) \\
16(0.04 \%)\end{array}$ & 42600 & 6089 & $\begin{array}{l}7(0.03 \%) \\
7(0.03 \%)\end{array}$ & 25042 & 2761 & $\begin{array}{l}1.07(0.44 ; 2.61) \\
1.11(0.46 ; 2.70)\end{array}$ \\
\hline $\begin{array}{c}\text { Immune system } \\
\text { disorders }\end{array}$ & 314 & 4 & $\begin{array}{l}4(0.01 \%) \\
4(0.01 \%)\end{array}$ & 67642 & 1121 & $\begin{array}{l}4(0.01 \%) \\
4(0.01 \%)\end{array}$ & 42600 & 727 & $\begin{array}{l}0(0 \%) \\
0(0 \%)\end{array}$ & 25042 & 394 & not estimable \\
\hline $\begin{array}{l}\text { Infections and } \\
\text { infestations }\end{array}$ & 314 & 88 & $\begin{array}{l}150(0.22 \%) \\
225(0.33 \%)\end{array}$ & 67642 & 28479 & $\begin{array}{l}103(0.24 \%) \\
152(0.36 \%)\end{array}$ & 42600 & 17966 & $\begin{array}{l}47(0.19 \%) \\
73(0.29 \%)\end{array}$ & 25042 & 10513 & $\begin{array}{l}1.47(1.02 ; 2.12) \\
1.43(1.06 ; 1.92)\end{array}$ \\
\hline $\begin{array}{c}\text { Injury, } \\
\text { poisoning and } \\
\text { procedural } \\
\text { complications }\end{array}$ & 314 & 105 & $\begin{array}{l}195(0.29 \%) \\
258(0.38 \%)\end{array}$ & 67642 & 35300 & $\begin{array}{c}128(0.3 \%) \\
168(0.39 \%)\end{array}$ & 42600 & 22843 & $\begin{array}{l}67(0.27 \%) \\
90(0.36 \%)\end{array}$ & 25042 & 12457 & $\begin{array}{l}1.15(0.85 ; 1.56) \\
1.13(0.87 ; 1.48)\end{array}$ \\
\hline Investigations & 314 & 34 & $\begin{array}{l}40(0.06 \%) \\
51(0.08 \%)\end{array}$ & 67642 & 9817 & $\begin{array}{l}28(0.07 \%) \\
36(0.08 \%)\end{array}$ & 42600 & 6736 & $\begin{array}{l}12(0.05 \%) \\
15(0.06 \%)\end{array}$ & 25042 & 3081 & $\begin{array}{l}1.23(0.61 ; 2.45) \\
1.25(0.67 ; 2.35)\end{array}$ \\
\hline $\begin{array}{l}\text { Metabolism and } \\
\text { nutrition } \\
\text { disorders }\end{array}$ & 314 & 39 & $\begin{array}{l}62(0.09 \%) \\
83(0.12 \%)\end{array}$ & 67642 & 14515 & $\begin{array}{c}43(0.1 \%) \\
56(0.13 \%)\end{array}$ & 42600 & 9518 & $\begin{array}{l}19(0.08 \%) \\
27(0.11 \%)\end{array}$ & 25042 & 4997 & $\begin{array}{l}1.25(0.70 ; 2.21) \\
1.12(0.69 ; 1.85)\end{array}$ \\
\hline $\begin{array}{l}\text { Musculoskeletal } \\
\text { and connective } \\
\text { tissue disorders }\end{array}$ & 314 & 29 & $\begin{array}{l}34(0.05 \%) \\
37(0.05 \%)\end{array}$ & 67642 & 10854 & $\begin{array}{l}27(0.06 \%) \\
29(0.07 \%)\end{array}$ & 42600 & 6931 & $\begin{array}{l}7(0.03 \%) \\
8(0.03 \%)\end{array}$ & 25042 & 3923 & $\begin{array}{l}2.51(1.05 ; 6.01) \\
2.46(1.08 ; 5.58)\end{array}$ \\
\hline $\begin{array}{l}\text { Neoplasms } \\
\text { benign, } \\
\text { malignant and } \\
\text { unspecified (incl } \\
\text { cysts and } \\
\text { polyps) } \\
\end{array}$ & 314 & 25 & $\begin{array}{l}27(0.04 \%) \\
34(0.05 \%)\end{array}$ & 67642 & 9055 & $\begin{array}{l}15(0.04 \%) \\
21(0.05 \%)\end{array}$ & 42600 & 6123 & $\begin{array}{l}12(0.05 \%) \\
13(0.05 \%)\end{array}$ & 25042 & 2932 & $\begin{array}{l}0.66(0.30 ; 1.46) \\
0.81(0.39 ; 1.66)\end{array}$ \\
\hline $\begin{array}{l}\text { Nervous system } \\
\text { disorders }\end{array}$ & 314 & 114 & $\begin{array}{l}175(0.26 \%) \\
271(0.4 \%)\end{array}$ & 67642 & 38436 & $\begin{array}{l}121(0.28 \%) \\
197(0.46 \%)\end{array}$ & 42600 & 25362 & $\begin{array}{l}54(0.22 \%) \\
74(0.3 \%)\end{array}$ & 25042 & 13074 & $\begin{array}{l}1.27(0.92 ; 1.76) \\
1.49(1.13 ; 1.96)\end{array}$ \\
\hline $\begin{array}{l}\text { Pregnancy, } \\
\text { puerperium and } \\
\text { perinatal } \\
\text { conditions }\end{array}$ & 314 & 5 & $\begin{array}{l}5(0.01 \%) \\
5(0.01 \%)\end{array}$ & 67642 & 2189 & $\begin{array}{l}2(0 \%) \\
2(0 \%)\end{array}$ & 42600 & 1476 & $\begin{array}{l}3(0.01 \%) \\
3(0.01 \%)\end{array}$ & 25042 & 713 & $\begin{array}{l}0.33(0.05 ; 2.28) \\
0.33(0.05 ; 2.28)\end{array}$ \\
\hline
\end{tabular}




\begin{tabular}{|c|c|c|c|c|c|c|c|c|c|c|c|c|}
\hline Product issues & 314 & 1 & $\begin{array}{l}1(0 \%) \\
1(0 \%)\end{array}$ & 67642 & 652 & $\begin{array}{l}1(0 \%) \\
1(0 \%)\end{array}$ & 42600 & 523 & $\begin{array}{l}0(0 \%) \\
0(0 \%)\end{array}$ & 25042 & 129 & not estimable \\
\hline $\begin{array}{l}\text { Renal and } \\
\text { urinary } \\
\text { disorders }\end{array}$ & 314 & 22 & $\begin{array}{l}23(0.03 \%) \\
30(0.04 \%)\end{array}$ & 67642 & 8709 & $\begin{array}{l}16(0.04 \%) \\
20(0.05 \%)\end{array}$ & 42600 & 5675 & $\begin{array}{c}7(0.03 \%) \\
10(0.04 \%)\end{array}$ & 25042 & 3034 & $\begin{array}{l}1.39(0.55 ; 3.51) \\
1.24(0.55 ; 2.76)\end{array}$ \\
\hline $\begin{array}{l}\text { Reproductive } \\
\text { system and } \\
\text { breast disorders }\end{array}$ & 314 & 9 & $\begin{array}{l}9(0.01 \%) \\
9(0.01 \%)\end{array}$ & 67642 & 3972 & $\begin{array}{l}5(0.01 \%) \\
5(0.01 \%)\end{array}$ & 42600 & 2467 & $\begin{array}{l}4(0.02 \%) \\
4(0.02 \%)\end{array}$ & 25042 & 1505 & $\begin{array}{l}0.81(0.20 ; 3.27) \\
0.81(0.20 ; 3.27)\end{array}$ \\
\hline $\begin{array}{l}\text { Respiratory, } \\
\text { thoracic and } \\
\text { mediastinal } \\
\text { disorders }\end{array}$ & 314 & 38 & $\begin{array}{l}55(0.08 \%) \\
76(0.11 \%)\end{array}$ & 67642 & 13007 & $\begin{array}{l}38(0.09 \%) \\
56(0.13 \%)\end{array}$ & 42600 & 8590 & $\begin{array}{l}17(0.07 \%) \\
20(0.08 \%)\end{array}$ & 25042 & 4417 & $\begin{array}{l}1.32(0.74 ; 2.36) \\
1.72(1.02 ; 2.89)\end{array}$ \\
\hline $\begin{array}{c}\text { Skin and } \\
\text { subcutaneous } \\
\text { tissue disorders }\end{array}$ & 314 & 16 & $\begin{array}{l}16(0.02 \%) \\
20(0.03 \%)\end{array}$ & 67642 & 6770 & $\begin{array}{l}12(0.03 \%) \\
15(0.04 \%)\end{array}$ & 42600 & 4422 & $\begin{array}{l}4(0.02 \%) \\
5(0.02 \%)\end{array}$ & 25042 & 2348 & $\begin{array}{l}1.76(0.55 ; 5.57) \\
1.67(0.60 ; 4.62)\end{array}$ \\
\hline $\begin{array}{c}\text { Social } \\
\text { circumstances }\end{array}$ & 314 & 11 & $\begin{array}{l}11(0.02 \%) \\
12(0.02 \%)\end{array}$ & 67642 & 4267 & $\begin{array}{l}6(0.01 \%) \\
7(0.02 \%)\end{array}$ & 42600 & 2616 & $\begin{array}{l}5(0.02 \%) \\
5(0.02 \%)\end{array}$ & 25042 & 1651 & $\begin{array}{l}0.80(0.24 ; 2.68) \\
0.91(0.28 ; 2.93)\end{array}$ \\
\hline $\begin{array}{l}\text { Surgical and } \\
\text { medical } \\
\text { procedures }\end{array}$ & 314 & 8 & $\begin{array}{l}21(0.03 \%) \\
23(0.03 \%)\end{array}$ & 67642 & 2430 & $\begin{array}{l}16(0.04 \%) \\
18(0.04 \%)\end{array}$ & 42600 & 1390 & $\begin{array}{l}5(0.02 \%) \\
5(0.02 \%)\end{array}$ & 25042 & 1040 & $\begin{array}{l}2.86(0.99 ; 8.23) \\
3.28(1.16 ; 9.28)\end{array}$ \\
\hline $\begin{array}{l}\text { Vascular } \\
\text { disorders }\end{array}$ & 314 & 33 & $\begin{array}{l}43(0.06 \%) \\
56(0.08 \%)\end{array}$ & 67642 & 12842 & $\begin{array}{c}30(0.07 \%) \\
41(0.1 \%)\end{array}$ & 42600 & 8340 & $\begin{array}{l}13(0.05 \%) \\
15(0.06 \%)\end{array}$ & 25042 & 4502 & $\begin{array}{l}1.40(0.69 ; 2.82) \\
1.82(0.97 ; 3.41)\end{array}$ \\
\hline
\end{tabular}

The number of studies with data $(\mathrm{K})$ includes studies where no event occurred. The proportion of patients with at least one event is with respect to the total number of patients with data on the outcome $(\mathrm{N})$, i.e., including all studies with data $(\mathrm{K})$. OR=odds ratio. $95 \% \mathrm{CI}=95 \%$ confidence interval. 


\section{REFERENCES}

1 Hert M de, Correll CU, Bobes J, et al. Physical illness in patients with severe mental disorders. I. Prevalence, impact of medications and disparities in health care. World psychiatry: official journal of the World Psychiatric Association (WPA) 2011; 10: 52-77.

2 Leucht S, Burkard T, Henderson J, Maj M, Sartorius N. Physical illness and schizophrenia. A review of the literature. Acta psychiatrica Scandinavica 2007; 116: 31733. doi:10.1111/j.1600-0447.2007.01095.x.

3 Hjorthøj C, Stürup AE, McGrath JJ, Nordentoft M. Years of potential life lost and life expectancy in schizophrenia. A systematic review and meta-analysis. The Lancet Psychiatry 2017; 4: 295-301. doi:10.1016/S2215-0366(17)30078-0.

4 Correll CU, Detraux J, Lepeleire J de, Hert M de. Effects of antipsychotics, antidepressants and mood stabilizers on risk for physical diseases in people with schizophrenia, depression and bipolar disorder. World psychiatry : official journal of the World Psychiatric Association (WPA) 2015; 14: 119-36. doi:10.1002/wps.20204.

5 Food and Drug Administration. Clinical Safety Data Management. Definitions and Standards for Expedited Reporting. Published in the Federal Register 1 March 1995; 60: 11284-87.

6 European Medicine Agency. ICH E2A Clinical safety data management. Definitions and standards for expedited reporting. CPMP/ICH/377/95 1 June 1995.

7 ICH Expert Working Group. ICH harmonised tripartite guideline. Clinical safety data management: Definitions and standards for expedited reporting. E2A 27 October 1994.

8 Schneider-Thoma J, Efthimiou O, Huhn M, et al. Second-generation antipsychotic drugs and short-term mortality. A systematic review and meta-analysis of placebo-controlled randomised controlled trials. The lancet. Psychiatry 2018; 5: 653-63. doi:10.1016/S22150366(18)30177-9.

9 Liberati A, Altman DG, Tetzlaff J, et al. The PRISMA statement for reporting systematic reviews and meta-analyses of studies that evaluate health care interventions: explanation and elaboration. PLoS medicine 2009; 6: e1000100. doi:10.1371/journal.pmed.1000100.

10 Higgins JPT, Green S. Cochrane handbook for systematic reviews of interventions. Version 5.1.0 (updated March 2011): The Cochrane Collaboration, 2011.

11 Wu T, Li Y, Liu G, Bian Z, Li J, Zhang J, Xie L, Ni J. Investigation of authenticity of 'claimed' randomized controlled trials (RCTs) and quality assessment of RCT reports published in China. Dublin, UK, 2006 23-26 Oct.

12 Woodhead M. 80\% of China's clinical trial data are fraudulent, investigation finds. BMJ (Clinical research ed.) 2016; 355: i5396. doi:10.1136/bmj.i5396.

13 Parry J. China vows to clamp down on academic fraud amid medical journal scandal. BMJ (Clinical research ed.) 2017; 357: j2970. doi:10.1136/bmj.j2970.

14 Tong Z, Li F, Ogawa Y, Watanabe N, Furukawa TA. Quality of randomized controlled trials of new generation antidepressants and antipsychotics identified in the China National Knowledge Infrastructure (CNKI). A literature and telephone interview study. BMC medical research methodology 2018; 18: 96. doi:10.1186/s12874-018-0554-2.

15 Cipriani A, Furukawa TA, Salanti G, et al. Comparative efficacy and acceptability of 21 antidepressant drugs for the acute treatment of adults with major depressive disorder. A systematic review and network meta-analysis. The Lancet 2018; 391: 1357-66. doi:10.1016/S0140-6736(17)32802-7.

16 Council for International Organizations of Medical Sciences. Benefit-risk balance for marketed drugs. Evaluating safety signals ; report of CIOMS Working Group IV. Geneva: CIOMS, 1998. 
17 MedDRA ${ }^{\circledR}$ the Medical Dictionary for Regulatory Activities terminology is the international medical terminology developed under the auspices of the International Conference on Harmonisation of Technical Requirements for Registration of Pharmaceuticals for Human Use (ICH). MedDRA ${ }^{\circledR}$ trademark is owned by IFPMA on behalf of ICH.

18 Efthimiou O. Practical guide to the meta-analysis of rare events. Evidence-based mental health 2018. doi:10.1136/eb-2018-102911.

19 Kuss O. Statistical methods for meta-analyses including information from studies without any events-add nothing to nothing and succeed nevertheless. Statistics in medicine 2015; 34: 1097-116. doi:10.1002/sim.6383.

20 Elbourne DR, Altman DG, Higgins JPT, Curtin F, Worthington HV, Vail A. Metaanalyses involving cross-over trials. Methodological issues. International Journal of Epidemiology 2002; 31: 140-49. doi:10.1093/ije/31.1.140.

21 Harbord RM, Egger M, Sterne JAC. A modified test for small-study effects in metaanalyses of controlled trials with binary endpoints. Statistics in medicine 2006; 25: 344357. doi:10.1002/sim.2380.

22 Turner RM, Jackson D, Wei Y, Thompson SG, Higgins JPT. Predictive distributions for between-study heterogeneity and simple methods for their application in Bayesian metaanalysis. Statistics in medicine 2015; 34: 984-98. doi:10.1002/sim.6381.

23 Gardner DM, Murphy AL, O’Donnell H, Centorrino F, Baldessarini RJ. International consensus study of antipsychotic dosing. The American journal of psychiatry 2010; 167: 686-93. doi:10.1176/appi.ajp.2009.09060802.

24 R Core Team. R: A language and environment for statistical Computing. http://www.Rproject.org/.

25 Schwarzer G. meta: General Package for Meta-Analysis. https://cran.rproject.org/web/packages/meta/meta.pdf (accessed Aug 08, 2018).

26 Chen Y, Chu H, Luo S, Nie L, Chen S. Bayesian analysis on meta-analysis of case-control studies accounting for within-study correlation. Statistical methods in medical research 2015; 24: 836-55. doi:10.1177/0962280211430889.

27 Viechtbauer W. Conducting Meta-Analyses in R with the metafor Package. J. Stat. Soft. 2010; 36. doi:10.18637/jss.v036.i03.

28 Lunn D, Spiegelhalter D, Thomas A, Best N. The BUGS project: Evolution, critique and future directions. Statistics in medicine 2009; 28: 3049-67. doi:10.1002/sim.3680.

29 Lunn DJ, Thomas A, Best N, Spiegelhalter D. WinBUGS - A Bayesian Modelling Framework: Concepts, Structure, and Extensibility. Statistics and Computing 2000; 10: 325-37. doi:10.1023/A:1008929526011.

30 Schünemann H, Brożek J, Guyatt G, Oxman A. Handbook for grading the quality of evidence and the strength of recommendations using the GRADE approach. Updated October 2013.

31 Heres S, Davis J, Maino K, Jetzinger E, Kissling W, Leucht S. Why olanzapine beats risperidone, risperidone beats quetiapine, and quetiapine beats olanzapine. An exploratory analysis of head-to-head comparison studies of second-generation antipsychotics. The American journal of psychiatry 2006; 163: 185-94. doi:10.1176/appi.ajp.163.2.185.

32 Rochon PA, Normand S-L, Gomes T, et al. Antipsychotic therapy and short-term serious events in older adults with dementia. Archives of internal medicine 2008; 168: 1090-96. doi:10.1001/archinte.168.10.1090.

33 Ray WA, Stein CM, Murray KT, et al. Association of Antipsychotic Treatment With Risk of Unexpected Death Among Children and Youths. JAMA psychiatry 2019; 76: 162-71. doi:10.1001/jamapsychiatry.2018.3421.

34 Packard K, Price P, Hanson A. Antipsychotic use and the risk of rhabdomyolysis. Journal of pharmacy practice 2014; 27: 501-12. doi:10.1177/0897190013516509. 
35 Tolppanen A-M, Koponen M, Tanskanen A, et al. Antipsychotic Use and Risk of Hospitalization or Death Due to Pneumonia in Persons With and Those Without Alzheimer Disease. Chest 2016; 150: 1233-41. doi:10.1016/j.chest.2016.06.004.

36 Sacchetti E, Turrina C, Valsecchi P. Cerebrovascular accidents in elderly people treated with antipsychotic drugs. A systematic review. Drug safety 2010; 33: 273-88. doi:10.2165/11319120-000000000-00000.

37 Nosè M, Recla E, Trifirò G, Barbui C. Antipsychotic drug exposure and risk of pneumonia. A systematic review and meta-analysis of observational studies. Pharmacoepidemiology and drug safety 2015; 24: 812-20. doi:10.1002/pds.3804.

38 Koponen M, Taipale H, Lavikainen P, et al. Antipsychotic Use and the Risk of Hip Fracture Among Community-Dwelling Persons With Alzheimer's Disease. The Journal of clinical psychiatry 2017; 78: e257-e263. doi:10.4088/JCP.15m10458.

39 Correll CU, Solmi M, Veronese N, et al. Prevalence, incidence and mortality from cardiovascular disease in patients with pooled and specific severe mental illness. A largescale meta-analysis of 3,211,768 patients and 113,383,368 controls. World psychiatry: official journal of the World Psychiatric Association (WPA) 2017; 16: 163-80. doi:10.1002/wps.20420.

40 Ray WA, Chung CP, Murray KT, Hall K, Stein CM. Atypical antipsychotic drugs and the risk of sudden cardiac death. The New England journal of medicine 2009; 360: 225-35. doi:10.1056/NEJMoa0806994.

41 Hägg S, Jönsson AK, Spigset O. Risk of venous thromboembolism due to antipsychotic drug therapy. Expert Opinion on Drug Safety 2009; 8: 537-47. doi:10.1517/14740330903117271.

42 Mackin P. Cardiac side effects of psychiatric drugs. Human psychopharmacology 2008; 23 Suppl 1: 3-14. doi:10.1002/hup.915. 